\title{
Strontium isotope constraints on fluid flow in the sheeted dike complex of fast spreading crust: Pervasive fluid flow at Pito Deep
}

\author{
A. K. Barker, L. A. Coogan, and K. M. Gillis \\ School of Earth and Ocean Sciences, University of Victoria, P.O. Box 3055 STN CSC, Victoria, British Columbia V8W \\ 3P6, Canada (akbarker@uvic.ca)

\section{Weis} \\ Pacific Centre for Isotopic and Geochemical Research, Department of Earth and Ocean Sciences, University of British \\ Columbia, 6339 Stores Road, Vancouver, British Columbia V6T 1Z4, Canada
}

[1] Fluid flow through the axial hydrothermal system at fast spreading ridges is investigated using the Srisotopic composition of upper crustal samples recovered from a tectonic window at Pito Deep (NE Easter microplate). Samples from the sheeted dike complex collected away from macroscopic evidence of channelized fluid flow, such as faults and centimeter-scale hydrothermal veins, show a range of ${ }^{87} \mathrm{Sr} /{ }^{86} \mathrm{Sr}$ from 0.7025 to 0.7030 averaging 0.70276 relative to a protolith with ${ }^{87} \mathrm{Sr} /{ }^{86} \mathrm{Sr}$ of $\sim 0.7024$. There is no systematic variation in ${ }^{87} \mathrm{Sr} /{ }^{86} \mathrm{Sr}$ with depth in the sheeted dike complex. Comparison of these new data with the two other localities that similar data sets exist for (ODP Hole 504B and the Hess Deep tectonic window) reveals that the extent of Sr-isotope exchange is similar in all of these locations. Models that assume that fluid-rock reaction occurs during one-dimensional (recharge) flow lead to significant decreases in the predicted extent of isotopic modification of the rock with depth in the crust. These model results show systematic misfits when compared with the data that can only be avoided if the fluid flow is assumed to be focused in isolated channels with very slow fluid-rock exchange. In this scenario the fluid at the base of the crust is little modified in ${ }^{87} \mathrm{Sr} /{ }^{86} \mathrm{Sr}$ from seawater and thus unlike vent fluids. Additionally, this model predicts that some rocks should show no change from the fresh-rock ${ }^{87} \mathrm{Sr} /{ }^{86} \mathrm{Sr}$, but this is not observed. Alternatively, models in which fluid-rock reaction occurs during upflow (discharge) as well as downflow, or in which fluids are recirculated within the hydrothermal system, can reproduce the observed lack of variation in ${ }^{87} \mathrm{Sr} /{ }^{86} \mathrm{Sr}$ with depth in the crust. Minimum time-integrated fluid fluxes, calculated from mass balance, are between 1.5 and $2.6 \times 10^{6} \mathrm{~kg} \mathrm{~m}^{-2}$ for all areas studied to date. However, new evidence from both the rocks and a compilation of vent fluid compositions demonstrates that some $\mathrm{Sr}$ is leached from the crust. Because this leaching lowers the fluid ${ }^{87} \mathrm{Sr} /{ }^{86} \mathrm{Sr}$ without changing the rock ${ }^{87} \mathrm{Sr} /{ }^{86} \mathrm{Sr}$, these mass balance models must underestimate the time-integrated fluid flux. Additionally, these values do not account for fluid flow that is channelized within the crust.

Components: 11,828 words, 10 figures, 2 tables.

Keywords: Sr isotopes; sheeted dike complex; hydrothermal alteration; ocean crust.

Index Terms: 3017 Marine Geology and Geophysics: Hydrothermal systems (0450, 1034, 3616, 4832, 8135, 8424); 3035 Marine Geology and Geophysics: Midocean ridge processes; 3616 Mineralogy and Petrology: Hydrothermal systems (0450, 1034, 3017, 4832, 8135, 8424). 
Received 15 November 2007; Revised 14 April 2008; Accepted 24 April 2008; Published 24 June 2008.

Barker, A. K., L. A. Coogan, K. M. Gillis, and D. Weis (2008), Strontium isotope constraints on fluid flow in the sheeted dike complex of fast spreading crust: Pervasive fluid flow at Pito Deep, Geochem. Geophys. Geosyst., 9, Q06010, doi:10.1029/ 2007GC001901.

\section{Introduction}

[2] Hydrothermal circulation at mid-ocean ridges plays a critical role in controlling the composition of the world's oceans, provides the energy and nutrients for extremophile organisms and generates ore deposits that can be of economic importance. Understanding the hydrothermal modification of the bulk composition of the crust is also important for quantifying the chemical inputs into subduction zones and recycling within the mantle [e.g., Hofmann and White, 1982]. However, our understanding of the subsurface processes operating in ridge axis hydrothermal systems is limited.

[3] At intermediate to fast spreading ridges, where the crustal structure is relatively simple, cold seawater migrates downward through the lava pile and sheeted dike complex and is heated and chemically modified through mineral precipitation and reaction with the crust as it goes. Eventually the chemically modified hot hydrothermal fluid discharges upward and exits the crust, either at focused vents or more diffusely after mixing with cooler pore fluids. It is widely believed that the main modification of the mineralogy and composition of the sheeted dike complex occurs within the recharge portion of the system [e.g., Alt, 1995; Teagle et al., 2003] with discharge being focused into small areas. The total fluid mass that passes through these systems, and the heat and chemical fluxes carried by the fluid, are poorly constrained. Additionally the extent of variability in these parameters is unclear. For example does the fluid flux depend on spreading rate or does it vary temporally at any given location? One way to better understand these systems is through the study of samples of the oceanic crust.

[4] Much previous study has concentrated on the record of hydrothermal circulation in rocks recovered by deep drilling, especially the core recovered from ODP Hole 504B [e.g., Alt et al., 1996b; Laverne et al., 2001; Teagle et al., 1998a, 1998b, 2003; Bach et al., 2003]. However, drill cores provide a largely one-dimensional view of the axial hydrothermal system and reveal little about the spatial variability of these systems. Studies of a tectonic exposure of the upper ocean crust at Hess Deep [Gillis, 1995; Gillis et al., 2001], and of on land exposures of oceanic crust formed at abnormal spreading centers (ophiolites [e.g., Schiffman et al., 1987]), have demonstrated the importance of threedimensional variability in hydrothermal systems. The approach used here to understand the processes operating in axial hydrothermal systems is to study a "tectonic window" at Pito Deep, in the southern Pacific. The crust has been dissected by faulting forming a "tectonic window" where laterally continuous upper crustal exposures allow the spatial and temporal variability in fluid flow to be investigated. Additionally, comparison of the hydrothermal fluxes through the sheeted dike complex at Pito Deep with those calculated from studies of previous crustal sections (ODP Hole 504B, Hess Deep) allows the global variability in hydrothermal fluxes to be investigated.

\subsection{Sr Isotope Exchange}

[5] The strontium isotopic composition of the oceanic crust currently provides arguably the most quantitative information about the amount of hydrothermal fluid that the crust has reacted with. This is in part due to the contrast in ${ }^{87} \mathrm{Sr} /{ }^{86} \mathrm{Sr}$ between fresh ocean crust $\left(\mathrm{Sr} \sim 100 \mathrm{ppm} ;{ }^{87} \mathrm{Sr} /{ }^{86} \mathrm{Sr} \sim\right.$ 0.7024-0.7025; PETDB: http://www.petdb.org) and seawater $\left(\mathrm{Sr} \sim 8 \mathrm{ppm},{ }^{87} \mathrm{Sr} /{ }^{86} \mathrm{Sr} \sim 0.7091\right.$ [Hess et al., 1986]). Additionally, the mobility of $\mathrm{Sr}$ in the presence of fluid at greenschist facies conditions promotes isotopic exchange between the hydrothermal fluid and rock it encounters. As discussed in more detail later, this means that the modification of the ${ }^{87} \mathrm{Sr} /{ }^{86} \mathrm{Sr}$ of the ocean crust allows the extent and variability of interaction between the fluid and crust to be assessed [e.g., Bickle and Teagle, 1992; Bickle et al., 1998; Davis et al., 2003; Bach et al., 2003; Teagle et al., 2003; Gillis et al., 2005]. Likewise, the ${ }^{87} \mathrm{Sr} /{ }^{86} \mathrm{Sr}$ of hydrothermal fluids venting from the crust provide insight into the amount of rock that the fluid has reacted with. At intermediate to fast spreading ridges the mean ${ }^{87} \mathrm{Sr} /{ }^{86} \mathrm{Sr}$ of vent fluids is 0.7038 [Bach and Humphris, 1999; Von Damm, 1990, 
1995; Palmer, 1992; Palmer and Edmond, 1989; Merlivat et al., 1987; Hinkley and Tatsumoto, 1987; Piepgras and Wasserburg, 1985; Albarède et al., 1981]. These fluid isotopic compositions can be used to calculate the amount of rock that the fluid reacted with but, as shown by Berndt et al. [1988], these calculations suffer considerable uncertainty in the absence of constraints from the composition of the rocks.

[6] Here we use the ${ }^{87} \mathrm{Sr} /{ }^{86} \mathrm{Sr}$ of a suite of samples recovered on a recent cruise to Pito Deep, together with supporting petrography and major and trace element analyses, to investigate the scale of variability in the extent of pervasive hydrothermal fluid flow at intermediate to fast spreading ridge axes. We focus on the alteration of the sheeted dike complex because this is the unit in which there is evidence for high-temperature alteration at conditions similar to those required to produce fluids with the compositions observed at hydrothermal vents [e.g., Seyfried, 1987; Alt, 1995; Gillis et al., 2001]. We show that the extent of Sr-isotopic exchange between the crust and hydrothermal fluids is very similar in all areas studied at intermediate to fast spreading ridges and requires a minimum of 1.5 to $2.6 \times 10^{6} \mathrm{~kg} \mathrm{~m}^{-2}$ of fluid to circulate through the crust. Additionally we suggest that the lack of variation in ${ }^{87} \mathrm{Sr} /{ }^{86} \mathrm{Sr}$ with depth in the crust is inconsistent with exchange of Sr between the fluid and rock occurring only during recharge and instead that reaction during discharge is required by the data.

\subsection{Defining Pervasive Fluid Flow}

[7] In this study we focus on "pervasive" fluid flow through the sheeted dike complex. We use this term to represent the fluid flow that leads to alteration that is relatively homogeneously distributed within the sheeted dike complex and contrasts with the alteration associated with focused fluid flow. The latter is generally associated with fluid flow in fault zones and mineralized veins that are tens of millimeters wide and is the subject of an ongoing study (A. K. Barker et al., manuscript in preparation, 2008). We consider this to be a logical division because this probably reflects two different permeability systems within the axial hydrothermal system, although, there must be a broad continuum between the two. We use the somewhat arbitrary definition that samples are associated with focused fluid flow if dive footage shows them to be within $2 \mathrm{~m}$ of a fault, breccia zone or regions of extensive hydrothermal veining at the sampling location on the seafloor. Additionally, samples containing veins $\geq 5 \mathrm{~mm}$ wide are also considered to have been associated with focused fluid flow. All other samples are assumed to have been exposed only to pervasive fluid flow. On the basis of these criteria 53 samples were chosen for this study to represent the pervasive hydrothermal fluid flow at Pito Deep.

[8] An important aspect of this study is the comparison of the samples recovered from Pito Deep with those from other areas, hence it is important to note the differences in sampling strategy in the different study areas. The most comparable sample suite is that from Hess Deep [Gillis et al., 2005]. Although these authors did not stringently filter their samples to avoid any from near fault zones they did not analyze samples from directly within fault zones. In contrast, samples from the full range of extent of deformation and alteration from ODP Hole 504B have been analyzed [Alt et al., 1996b]. Further comparison between these different study areas is given in Table 1.

\section{Geological Background}

[9] Pito Deep is located at the northeast corner of the Easter microplate (Figure 1a) [Francheteau et al., 1988], where a tectonic window exposes $\sim 3$ Ma old ocean crust formed at a fast spreading ridge at a full spreading rate of $142 \mathrm{~mm} / \mathrm{a}$ [Hey et al., 1995]. Rifting and rotation at the north edge of the Easter microplate faulted and exposed the ocean crust at Pito Deep within the last million years [Hey et al., 2002]. During cruise AT11-23 of the R/V Atlantis in February 2005 to Pito Deep, two escarpments were sampled by the ROV Jason II and the Alvin submersible by prizing samples from outcrop leading to in situ sampling of multiple densely sampled dive transects (Figure 1). These two escarpments are referred to as Areas A and B; the former is located west of the latter. Volcanic rocks make up the upper $300-500 \mathrm{~m}$ of each crustal section and are underlain by $650-1100 \mathrm{~m}$ of sheeted dikes [Heft et al., 2008; Karson and Pito Deep Shipboard Scientific Party, 2005]. The base of the sheeted dike complex is only exposed in Area B where $\sim 900 \mathrm{~m}$ of gabbros are exposed [Perk et al., 2007]. The escarpments trend perpendicular to the strike of the dikes providing a crosssection through the crust [Hey et al., 2002; Karson and Pito Deep Shipboard Scientific Party, 2005]. 
Table 1. Summary of Characteristics of Sheeted Dikes at Pito Deep, Hess Deep, and ODP Hole 504B ${ }^{\mathrm{a}}$

\begin{tabular}{|c|c|c|c|c|c|}
\hline & \multirow[b]{2}{*}{ Pito Deep } & \multirow[b]{2}{*}{ Hess Deep } & \multirow[b]{2}{*}{$504 \mathrm{~B}$} & \multicolumn{2}{|c|}{ Pito Deep } \\
\hline & & & & Area A & Area B \\
\hline Age (Ma) & 3 & 1 & 6.9 & & \\
\hline $\begin{array}{l}\text { Spreading rate } \\
\left(\mathrm{mm} \mathrm{a}^{-1}\right)\end{array}$ & 142 & 130 & 66 & & \\
\hline $\begin{array}{l}\text { Thickness of Sheeted } \\
\text { Dikes (m) }\end{array}$ & $650-1100$ & $200-1000$ & $>1050$ & & \\
\hline \multicolumn{6}{|l|}{ Protolith } \\
\hline Mg\# (mean) & 55 & 50 & - & 60 & 55 \\
\hline $\mathrm{Mg \#}$ range & $42-68$ & $52-66$ & $63-74$ & $42-68$ & $49-60$ \\
\hline $\mathrm{An}^{\mathrm{b}}$ & $<0.7$ & $<0.7$ & $>0.7$ & & \\
\hline $\begin{array}{l}\text { Extent of cpx } \\
\text { alteration \% }\end{array}$ & $<10->85$ & $<10-40$ & $5-40$ & & \\
\hline Mean Sr (ppm) & 95 & 90 & 60 & 100 & 95 \\
\hline${ }^{87} \mathrm{Sr} /{ }^{86} \mathrm{Sr}$ & $0.70239-0.70242$ & $0.70243-0.70245$ & $0.70245^{\mathrm{a}}$ & & \\
\hline
\end{tabular}

[10] Samples for this study were selected to provide as complete a vertical profile through the upper ocean crust as possible. In Area A, three adjacent and overlapping dives provided lateral coverage of $\sim 500 \mathrm{~m}$ and a depth range of $\sim 1000 \mathrm{~m}$; the sample density in the lower $200 \mathrm{~m}$ of dives J2-119-1 and J2-119-2 was restricted by the occurrence of faulting and macroscopic veining (Figure 1a). In Area B, five adjacent and overlapping dives provided lateral coverage of $\sim 1000 \mathrm{~m}$ at near-constant depth between 100 and $400 \mathrm{~m}$ below the lava-dike transition and a depth range of $\sim 1300 \mathrm{~m}$. There is a gap in sampling between 450 and $1050 \mathrm{~m}$ in Area B J2-123-4 due to talus concealing the exposure (Figure 1b) [Karson and Pito Deep Shipboard Scientific Party, 2005]. An important datum for this study is the lava-dike transition, which is defined here as the depth of the deepest lava in each dive transect and data are plotted with depths relative to this transition in all figures.

\section{Analytical Methods}

[11] Weathered edges and alteration haloes were removed from the samples prior to jaw crushing; subsequently samples were ground in an agate mill. Trace element analyses were performed on whole rock powders, $100 \mathrm{mg}$ of sample was digested with $\mathrm{HF}-\mathrm{HNO}_{3}$ and $8 \mathrm{~N} \mathrm{HNO}_{3}$, and diluted by a factor of $1: 1000$ in $2 \% \mathrm{HNO}_{3}$ solution. Trace elements were analyzed using a Thermo X Series II induc- tively coupled plasma mass spectrometry (ICPMS) following the approach of Eggins et al. [1997] at the University of Victoria. BIR-1 was routinely measured to monitor for drift, and DNC-1, W2-A, BCR-2, BHVO-2 rock standards were analyzed for calibration at the start and end of analytical sessions (auxiliary material ${ }^{1}$ Data Set S1).

[12] $\mathrm{The}{ }^{87} \mathrm{Sr} /{ }^{86} \mathrm{Sr}$ of lavas and dikes were measured on unleached whole rock powders on 40 of the 53 samples. The $\mathrm{Sr}$ isotope ratios of epidote separates from two quartz-epidote veins were also determined. An estimate of the ${ }^{87} \mathrm{Sr} /{ }^{86} \mathrm{Sr}$ of fresh ocean crust at Pito Deep and Hess Deep was made on the basis of analysis of leached plagioclase separates of the least altered gabbros from the underlying crust [Perk et al., 2007; Coogan et al., 2002; Francheteau et al., 1990]. Plagioclase separates were leached in hot $6 \mathrm{~N} \mathrm{HCl}$ for $30 \mathrm{~min}$ prior to digestion. Strontium was separated by standard cation exchange techniques [Weis et al., 2006] and measured using a Triton thermal ionization mass spectrometry at the Pacific Centre for Isotopic and Geochemical Research, University of British Columbia. The NBS 987 standard gave ${ }^{87} \mathrm{Sr} /{ }^{86} \mathrm{Sr}$ of $0.710251 \pm 0.000017$ (2 s.d., $\mathrm{n}=26$ ), the maximum difference between duplicates was \pm 0.000022 with an average reproducibility

\footnotetext{
${ }^{1}$ Auxiliary materials are available at $\mathrm{ftp} / / / \mathrm{ftp}$.agu.org/apend/gc/ $2007 \mathrm{gc} 001901$.
} 

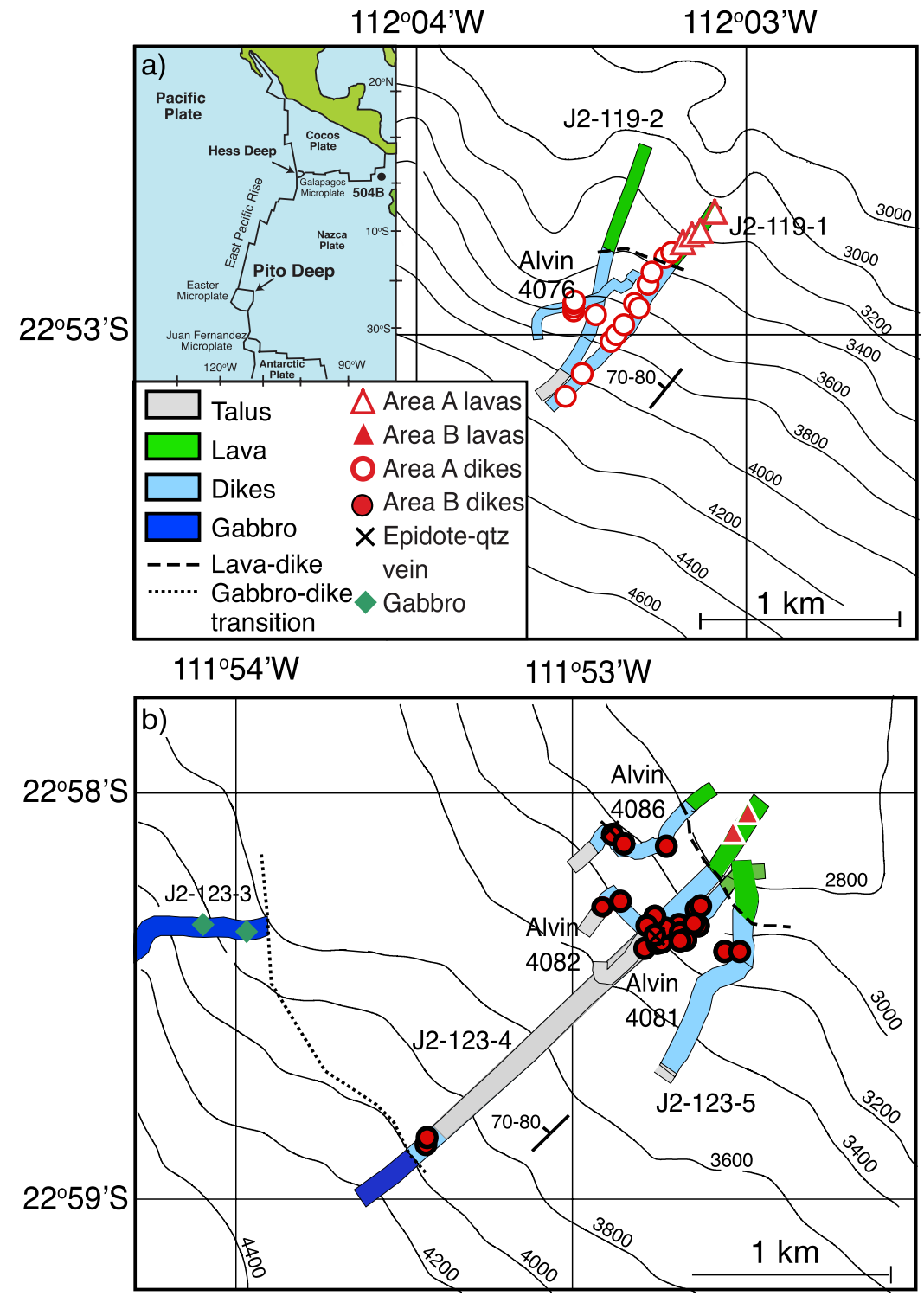

Figure 1. (a) Locations of dive transects and samples studied in Area A. Inset shows map of Pito Deep at northeast of Easter microplate and relative locations of Hess Deep and ODP Hole 504B. (b) Locations of dive transects and samples studied in Area B [Karson and Pito Deep Shipboard Scientific Party, 2005]. Lava-dike transition is gradual with dikes intruding lavas to different extents (Pollock et al., submitted manuscript, 2008). Faults occur at high angles and subparallel to the strike of the sheeted dikes, with examples of sheeted dikes crosscutting fault zones indicating formation at the ridge axis [Karson and Pito Deep Shipboard Scientific Party, 2005].

$\pm 0.000012( \pm 8,1$ s.d.), the Sr blank measured over the course of the study was $13 \mathrm{pg}$.

\section{Results}

\subsection{Petrography of the Lavas and Sheeted Dike Complex}

[13] Volcanic rocks from Pito Deep have visually estimated abundances of secondary minerals in thin section ranging from 10 to $40 \%$ of the rock. Clay minerals and oxyhydroxide replace the primary minerals in the upper volcanics and amphibole and albite in the lava-dike transition zone. Sheeted dikes at Pito Deep range from aphyric basalts to porphyritic and equigranular basalts with minimal interstitial phases. The samples range in grain size from very fine to $\sim 0.4 \mathrm{~mm}$, perhaps representing the center of sheeted dikes opposed to chilled margins. Primary plagioclase is altered to secondary plagioclase \pm amphibole, \pm chlorite, $\pm \mathrm{Fe}$-oxides and rare epidote. Clinopyroxene ranges from fresh through partially replaced by amphibole, \pm chlorite, 
\pm minor Fe-oxides and rare secondary clinopyroxene. Amphibole and chlorite often occur together in the groundmass. In general the alteration assemblages are dominated by amphibole (auxiliary material Data Set S1) [Heft et al., 2008]. Similar alteration to amphibole-dominated assemblages is observed in the sheeted dikes from ODP Hole 504B with chlorite dominated assemblages concentrating in the upper $400 \mathrm{~m}$ of the sheeted dike complex [Laverne et al., 1995, 2001; Vanko et al., 1996; Alt et al., 1989, 1996b], whereas sheeted dikes from Hess Deep show more variability in alteration assemblages with a greater occurrence of chlorite dominated (57\%) than amphibole dominated assemblages $(43 \%, \mathrm{n}=26)$ in samples with $\mathrm{Sr}$ isotope data [Gillis et al., 2005].

[14] Samples exhibit patches of contrasting alteration, which tend toward chlorite-dominated assemblages. Patches are typically $1-2 \mathrm{~mm}$ in diameter and are composed of chlorite, \pm plagioclase, \pm quartz, \pm sulphides, \pm epidote, \pm amphibole. A patch bearing sample typically hosts a single patch. Patches are more prevalent in Area A with $20 \%$ of samples hosting patches as opposed to $15 \%$ in Area B ( $\mathrm{n}=20$ and 33, respectively). Veins are common in thin section with $50 \%$ of the samples hosting from one to ten veins of $0.015 \mathrm{~mm}$ to $0.7 \mathrm{~mm}$ width. Vein mineralogy includes amphibole, chlorite, quartz, epidote and sulphides. Epidote most commonly occurs in association with patches or veins but also occurs as an alteration product of plagioclase away from patches and veins. Thin veins $\sim 1 \mathrm{~mm}$ wide visible in hand specimen are more abundant in Area B, which hosts veins in $58 \%$ of samples whereas Area A hosts veins in $45 \%$ of samples ( $\mathrm{n}=33$ and 20, respectively).

[15] The extent of alteration in samples from Pito Deep was visually estimated from the modal proportion of secondary minerals. There is a wide petrographic range in the extent of total alteration at Pito Deep from $<10$ to $>85 \%$ [Heft et al., 2008; this study]. Areas A and B show similar extents of total alteration averaging $34 \%( \pm 17,1$ s.d.). Clinopyroxene is similarly altered between $<10$ and $>95 \%$, with an average of $33 \%( \pm 22,1$ s.d.). Heft et al. [2008] show that there are no systematic spatial trends in alteration assemblages and that degree of alteration and amphibole abundance do not correlate with depth.

\subsection{Protolith Composition}

[16] The dikes and lavas at the Pito Deep are typical moderately fractionated N-MORB
[Hékinian et al., 1996; Heft et al., 2008; this study; M. A. Pollock et al., Compositions of dikes and lavas from the Pito Deep Rift: Implications for crustal accretion at superfast spreading centers, submitted to Journal of Geophysical Research, 2008]. There are small differences in the primary (magmatic) composition of the dikes between Areas $\mathrm{A}$ and $\mathrm{B}$; the mean $\mathrm{Mg} \#(\mathrm{Mg} \#=\mathrm{Mg} / \mathrm{Mg}+$ $\mathrm{Fe})$ molar) is $60 \pm 13$ (1 s.d.) in Area A and $55 \pm 6$ (1 s.d.) in Area B [Hékinian et al., 1996; Heft et al., 2008; Pollock et al., submitted manuscript, 2008]. The Sr contents of the sheeted dike samples in Area A average $100 \pm 10$ (1 s.d.) ppm, whereas $\mathrm{Sr}$ concentrations in samples at Area B are slightly lower with an average of $95 \pm 6$ (1 s.d.) ppm Sr. These small differences in protolith composition are expected to be insignificant in controlling the exchange of Sr-isotopes between the crust and hydrothermal fluids.

\subsection{Strontium Isotopic Composition of the Ocean Crust From Pito Deep}

[17] The extent of hydrothermal enrichment of ${ }^{87} \mathrm{Sr} /{ }^{86} \mathrm{Sr}$ in the Pito Deep ocean crust requires knowledge of the ${ }^{87} \mathrm{Sr} /{ }^{86} \mathrm{Sr}$ of the local fresh protolith. We have determined the protolith ${ }^{87} \mathrm{Sr} /{ }^{86} \mathrm{Sr}$ from leached plagioclase separated from the least altered gabbros from Pito Deep and ${ }^{87} \mathrm{Sr} /{ }^{86} \mathrm{Sr}$ of proximal MORB currently at the East Pacific Rise (EPR) between 22 and $23^{\circ} \mathrm{S}$. The plagioclase separates have ${ }^{87} \mathrm{Sr} /{ }^{86} \mathrm{Sr}$ of 0.70237 to 0.70239 (auxiliary material Data Set S1) and local fresh MORB have ${ }^{87} \mathrm{Sr} /{ }^{86} \mathrm{Sr}$ between 0.70239 and 0.70242 [Mahoney et al., 1994]. On the basis of these data we assume a range of initial (i.e., magmatic) ${ }^{87} \mathrm{Sr} /{ }^{86} \mathrm{Sr}$ of 0.70237 to 0.70242 for Pito Deep ocean crust. To supplement the data set of Gillis et al. [2005] on altered dikes and lavas from Hess Deep we have analyzed plagioclase separates from gabbros to define the composition of fresh crust at Hess Deep. Plagioclase separates from least altered gabbros at Hess Deep have ${ }^{87} \mathrm{Sr} /{ }^{86} \mathrm{Sr}$ of 0.70243 and 0.70245 (auxiliary material Data Set S1).

[18] The Sr isotopic composition of six Pito Deep lavas sampled from a $280 \mathrm{~m}$ depth interval range from ${ }^{87} \mathrm{Sr} /{ }^{86} \mathrm{Sr}$ of 0.70257 to 0.70363 (Figure 2). The Sr isotope compositions of the Pito Deep lavas do not correlate with alteration assemblages, extent of total or clinopyroxene alteration or alkali element concentration. For comparison two lavas with $\mathrm{Sr}$ isotope data from younger crust at Hess Deep have ${ }^{87} \mathrm{Sr} /{ }^{86} \mathrm{Sr}$ of 0.70255 and 0.70260 [Gillis et al., 2005], similar to the lowest ${ }^{87} \mathrm{Sr} /{ }^{86} \mathrm{Sr}$ values 
${ }^{87} \mathrm{Sr} /{ }^{86} \mathrm{Sr}$

$\begin{array}{llllll}0.7020 & 0.7025 & 0.7030 & 0.7035 & 0.7040 & 0.7045\end{array}$

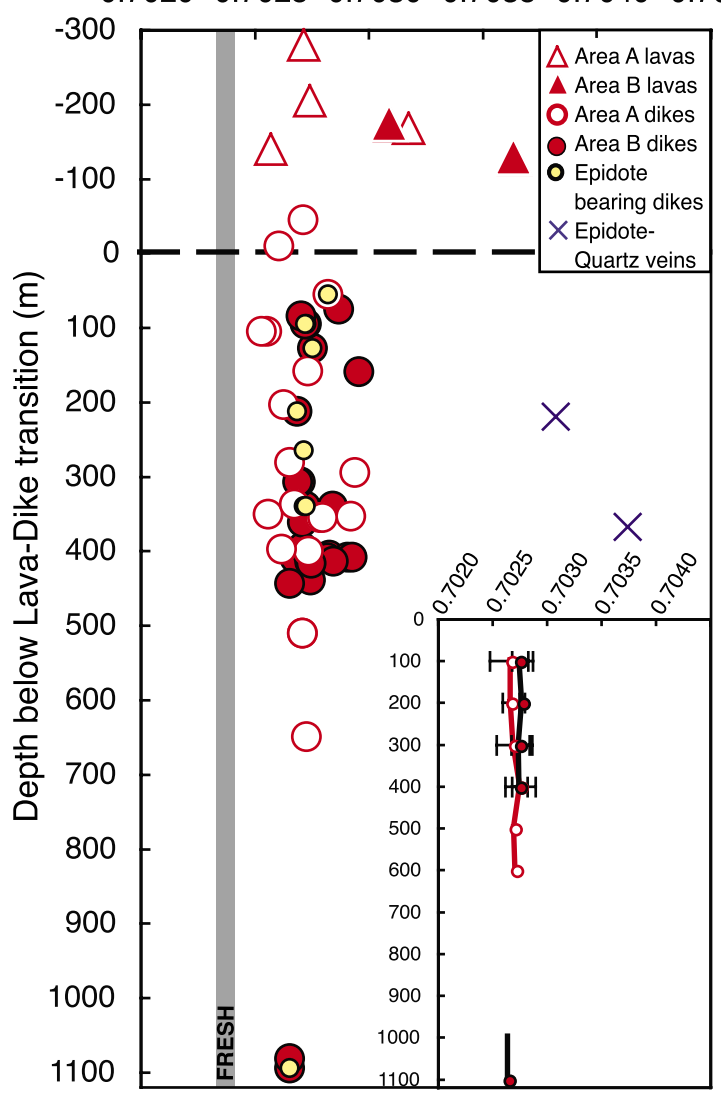

Figure 2. Values of ${ }^{87} \mathrm{Sr} /{ }^{86} \mathrm{Sr}$ with depth below the lava-dike transition for lavas and dikes at Pito Deep. Area A and B samples are separated into open and filled symbols, respectively. Inset shows mean ${ }^{87} \mathrm{Sr} /{ }^{86} \mathrm{Sr} \pm$ 1 s.d. with depth at $100 \mathrm{~m}$ depth intervals for sheeted dikes from Areas A and B.

observed at Pito Deep. The extensive analyses for the older lavas at ODP Hole 504B, sampled over a $570 \mathrm{~m}$ depth interval range in ${ }^{87} \mathrm{Sr} /{ }^{86} \mathrm{Sr}$ from 0.70255 to 0.70488 [Bach et al., 2003; Teagle et al., 1998a, 1998b, 2003; Alt et al., 1996a, 1996b]. Wide ranges in $\mathrm{Sr}$ isotopic composition as observed are expected of the variable low temperature alteration from heterogeneous fluid flow that occurs in high-permeability volcanics [Alt et al., 1996b; Kusakabe et al., 1989].

[19] The $\mathrm{Sr}$ isotopic composition of the sheeted dikes at Pito Deep range from ${ }^{87} \mathrm{Sr} /{ }^{86} \mathrm{Sr}$ of 0.70252 to 0.70295 (auxiliary material Data Set S1 and Figure 2). There is no observed change in ${ }^{87} \mathrm{Sr} /{ }^{86} \mathrm{Sr}$ with depth and the deepest dike samples at $1100 \mathrm{~m}$ below the lava-dike transition have ${ }^{87} \mathrm{Sr} /{ }^{86} \mathrm{Sr}$ of 0.70265 , well above the lowest ${ }^{87} \mathrm{Sr} /{ }^{86} \mathrm{Sr}$ and closer to the mean ${ }^{87} \mathrm{Sr} /{ }^{86} \mathrm{Sr}$ of 0.70276 for dikes at Pito Deep. The sheeted dikes in the two escarpments sampled at Pito Deep have similar $\mathrm{Sr}$ isotopic compositions; in Area A sheeted dikes have ${ }^{87} \mathrm{Sr} /{ }^{86} \mathrm{Sr}$ of 0.70252 to 0.70293 and in Area B the range is from 0.70265 to 0.70295 (Figure 2). All of the sheeted dikes at Pito Deep have Sr isotope compositions more radiogenic than that of the protolith $\left({ }^{87} \mathrm{Sr} /{ }^{86} \mathrm{Sr}\right.$ between 0.70237 to 0.70242$)$ demonstrating that all samples have exchanged $\mathrm{Sr}$ with hydrothermal fluids. There are no spatial groupings of $\mathrm{Sr}$ isotope composition instead the entire range of ${ }^{87} \mathrm{Sr} /{ }^{86} \mathrm{Sr}$ in the sheeted dike complex can be found in adjacent samples and transects.

[20] Epidote was separated from two centimeterscale quartz-epidote veins from Area B that occur $220 \mathrm{~m}$ and $370 \mathrm{~m}$ below the lava-dike transition. These have ${ }^{87} \mathrm{Sr} /{ }^{86} \mathrm{Sr}$ of 0.70382 and 0.70413 similar to epidote veins from ODP Hole 504B $\left({ }^{87} \mathrm{Sr} /{ }^{86} \mathrm{Sr}\right.$ of 0.7034 to 0.7038 [Teagle et al., 1998b]). Proximal sheeted dikes have ${ }^{87} \mathrm{Sr} /{ }^{86} \mathrm{Sr}$ of 0.70270 and 0.70271 (Samples 4086-1711 at $2 \mathrm{~m}$ and 022205-0941 at $15 \mathrm{~m}$ from vein). These quartz-epidote veins have ${ }^{87} \mathrm{Sr} /{ }^{86} \mathrm{Sr}$ similar to average vent fluids at intermediate to fast spreading ridges suggesting that these epidote veins were precipitated after the fluid has undergone most or all of its Sr-isotopic exchange with the crust.

\subsection{Mineralogical Controls on the Sr- Isotopic Composition of the Sheeted Dikes}

[21] If the exchange of $\mathrm{Sr}$ between a hydrothermal fluid and the crust is dominantly controlled by the minerals forming in the rock then this would have to be accounted for in modeling the Sr-isotopic composition of the crust to better understand hydrothermal circulation. For example, Gillis et al. [2005] found that, compared to the protolith, samples from Hess Deep that contained epidote were elevated in $\mathrm{Sr}$ and in ${ }^{87} \mathrm{Sr} /{ }^{86} \mathrm{Sr}$ whereas those that did not contain epidote were depleted in $\mathrm{Sr}$ and enriched somewhat less in ${ }^{87} \mathrm{Sr} /{ }^{86} \mathrm{Sr}$. The enrichment of $\mathrm{Sr}$ in rocks containing epidote can be explained by the high partition coefficient for $\mathrm{Sr}$ into epidote assuming that it grew in the presence of sufficient fluid to supply Sr. Seven of the sheeted dikes from Pito Deep studied here contain epidote. These are not significantly enriched in either $\mathrm{Sr}$ concentration or ${ }^{87} \mathrm{Sr} /{ }^{86} \mathrm{Sr}$ relative to the other samples (Figure 2). There is also no correlation of the modal proportions of chlorite or amphibole, or grain size, with ${ }^{87} \mathrm{Sr} /{ }^{86} \mathrm{Sr}$. Likewise, the alkali elements that are commonly enriched in 


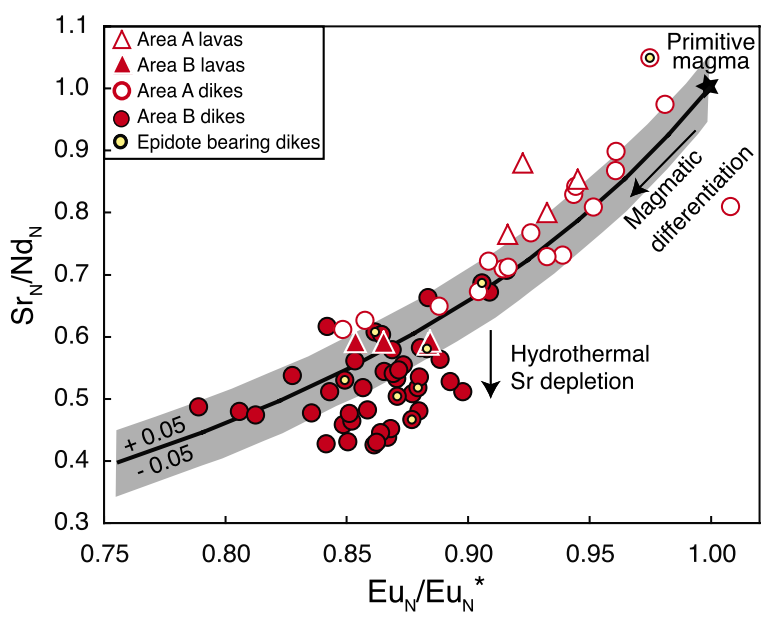

Figure 3. $\mathrm{Sr}_{\mathrm{N}} / \mathrm{Nd}_{\mathrm{N}}$ versus $\mathrm{Eu}_{\mathrm{N}} / \mathrm{Eu}_{\mathrm{N}}$ * for sheeted dikes from Pito Deep, Areas A and B. Black line marks the magmatic differentiation trend; gray shaded area marks deviation of $\pm 0.05 \mathrm{Sr}_{\mathrm{N}} / \mathrm{Nd}_{\mathrm{N}}$ from the magmatic differentiation trend. Hydrothermal mobilization of $\mathrm{Sr}$ is represented by deviations in $\operatorname{Sr}_{\mathrm{N}} / \mathrm{Nd}_{\mathrm{N}}(>0.05)$ at constant $\mathrm{Eu}_{\mathrm{N}} / \mathrm{Eu}_{\mathrm{N}} *$ from the magmatic trend. Magmatic trend is calculated by equilibrium fractional crystallization of plagioclase with $\mathrm{Kd}$ (plag/liq) for $\mathrm{Sr}=1.554$, $\mathrm{Nd}=0.014, \mathrm{Eu}=0.332, \mathrm{Sm}=0.009$, and $\mathrm{Gd}=0.007$ [McKay et al., 1994]. Variations in $\mathrm{Sr}_{\mathrm{N}} / \mathrm{Nd}_{\mathrm{N}}$ do not correlate with ${ }^{87} \mathrm{Sr} /{ }^{86} \mathrm{Sr}$, indices of albitization such as $\mathrm{Na}$, alteration degree, or assemblages.

minerals that form at low temperatures, such as clays, show no correlation with ${ }^{87} \mathrm{Sr} /{ }^{86} \mathrm{Sr}$. It is difficult in thin section to accurately assess the amount of secondary (albitic) plagioclase in a sample. Thus to assess the role of albitization in Sr-mobility we use bulk-rock chemical proxies for this process. There are no correlations between $\mathrm{Na}$, $\mathrm{Ca}$, or ratios such as $\mathrm{Na} / \mathrm{Y}, \mathrm{Ca} / \mathrm{Na}$ and $\mathrm{Sr}$ concentration, indicating that albitization is not a factor influencing $\mathrm{Sr}$ behavior during alteration.

\section{Data Analysis and Modeling}

[22] With the data presented above there are now three areas of oceanic crust formed at intermediate to fast spreading ridges that the Sr-isotopic composition of the sheeted dike complex has been determined for: Pito Deep, Hess Deep and ODP Hole 504B. In this section we use these three data sets to address three questions: (1) How variable is the extent of Sr-isotopic exchange between hydrothermal fluids and the crust in these areas? (2) What range of time-integrated fluid fluxes through the sheeted dike complex do these data suggest? (3) Are these data consistent with fluid-rock reaction occurring within the recharge portion of the hydrothermal system? However, before addressing these issues we consider whether $\mathrm{Sr}$ behaves conservatively within the axial hydrothermal system, as has previously been proposed, or not.

\subsection{How Mobile is Strontium During Hydrothermal Circulation?}

[23] In order to use $\mathrm{Sr}$ isotopes to trace the fluidrock reaction we need to understand the controls on the behavior of $\mathrm{Sr}$ concentration during hydrothermal alteration. The concentration of $\mathrm{Sr}$ in mid-ocean ridge basalts (MORB) remains approximately constant during differentiation so that defining fractionation trends is not simple. We consider the variations between $\mathrm{Sr}$ and REE illustrated as $\mathrm{Sr}_{\mathrm{N}} / \mathrm{Nd}_{\mathrm{N}}$ and $\mathrm{Eu}_{\mathrm{N}} / \mathrm{Eu}_{\mathrm{N}}{ }^{*}$, where concentrations are normalized to chondrite $(\mathrm{N})$ and $\mathrm{Eu}_{\mathrm{N}} / \mathrm{Eu}_{\mathrm{N}} *$ is the Europium anomaly which represents deviations in $\mathrm{Eu}_{\mathrm{N}}$ with respect to neighboring REEs, $\mathrm{Sm}_{\mathrm{N}}$ and $\mathrm{Gd}_{\mathrm{N}}$. A primitive magma has $\mathrm{Sr}_{\mathrm{N}} /$ $\mathrm{Nd}_{\mathrm{N}}$ and $\mathrm{Eu}_{\mathrm{N}} / \mathrm{Eu}_{\mathrm{N}}{ }^{*}$ of $\sim 1$ and crystallization of plagioclase fractionates $\mathrm{Sr}$ from $\mathrm{Nd}$, and $\mathrm{Eu}^{2+}$ from $\mathrm{Sm}$ and $\mathrm{Gd}$ causing the $\mathrm{Sr}$ and $\mathrm{Eu}$ content of the melt to decrease relative to the other REE. Figure 3 illustrates the curved trend expected from magmatic differentiation between $\mathrm{Sr}_{\mathrm{N}} / \mathrm{Nd}_{\mathrm{N}}$ and $\mathrm{Eu}_{\mathrm{N}} / \mathrm{Eu}_{\mathrm{N}}{ }^{*}$. Comparing Pito Deep samples to this magmatic differentiation trend allows assessment of the effects of magmatic differentiation and hydrothermal alteration on the $\mathrm{Sr}$ concentration of samples (Figure 3). Hydrothermal leaching or precipitation of $\mathrm{Sr}$ is expected to result in vertical deviations from this trend due to the immobility of REE during hydrothermal alteration [e.g., Bau, 1991].

[24] Lavas from Pito Deep generally have $\mathrm{Sr}_{\mathrm{N}} / \mathrm{Nd}_{\mathrm{N}}$ at given $\mathrm{Eu}_{\mathrm{N}} / \mathrm{Eu}_{\mathrm{N}} *$ close to the magmatic trend, with just one showing elevated $\mathrm{Sr}_{\mathrm{N}} / \mathrm{Nd}_{\mathrm{N}}$ over the magmatic trend, indicating gain of Sr. Sheeted dikes from Area $\mathrm{A}$ also have $\mathrm{Sr}_{\mathrm{N}} / \mathrm{Nd}_{\mathrm{N}}$ at given $\mathrm{Eu}_{\mathrm{N}} / \mathrm{Eu}_{\mathrm{N}} *$ close to the magmatic trend, with one sample showing significant $\mathrm{Sr}$ loss and another $\mathrm{Sr}$ gain. Sheeted dike samples from Area B have a wider range in deviation of $\mathrm{Sr}_{\mathrm{N}} / \mathrm{Nd}_{\mathrm{N}}$ from the magmatic trend with $45 \%$ of the samples showing Sr depletion $(>0.05$ units below the magmatic trend which is equivalent to $\sim 9 \mathrm{ppm}$ loss of $\mathrm{Sr}$ ). Altogether, strontium is depleted in $\sim 30 \%$ of the sheeted dikes, depleted samples show no consistent spatial distribution. Strontium depletion does not correlate with ${ }^{87} \mathrm{Sr} /{ }^{86} \mathrm{Sr}$ unlike in samples from Hess Deep [Gillis et al., 2005]. However, as with samples from Hess Deep it is clear that $\mathrm{Sr}$ is 


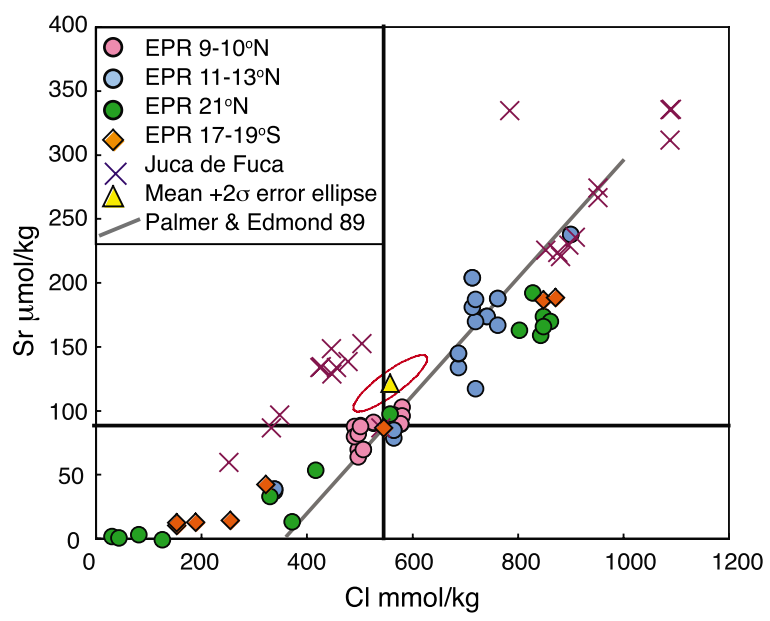

Figure 4. $\mathrm{Sr}$ versus $\mathrm{Cl}$ concentrations in vent fluids from the EPR and Juan de Fuca ridge. Gray line marks correlation of Palmer and Edmond [1989]. Solid black lines mark seawater composition. Mean vent fluid plotted with a $2 \sigma$ error ellipse to represent statistical uncertainties; in reality, many other factors influence the geological uncertainty. Juan de Fuca and southern EPR vent fluid data plotted as zero-Mg end-member fluids [Butterfield et al., 1994; Butterfield and Massoth, 1994; Charlou et al., 1996]. Vent fluid data from EPR $9-10^{\circ} \mathrm{N}$ are zero-Mg end-member fluids, a number of which have negative Sr; therefore the measured fluids would have higher Sr concentrations [Von Damm, 2000]. Data sources: Von Damm [1990, 1995, 2000], Palmer and Edmond [1989], Palmer [1992], Butterfield et al. [1994], Butterfield and Massoth [1994], Charlou et al. [1996].

leached from the sheeted dike complex during hydrothermal circulation.

[25] Since there is strong evidence that $\mathrm{Sr}$ is leached from the sheeted dike complex during hydrothermal alteration we reconsider the previous interpretation that $\mathrm{Sr}$ behaves conservatively with the average Sr content of vent fluids matching that of seawater [Palmer and Edmond, 1989; Davis et al., 2003]. Figure 4 shows a compilation of $\mathrm{Sr}$ versus $\mathrm{Cl}$ data for vent fluids for the EPR and Juan de Fuca ridges. The majority of the samples follow the linear correlation observed by Palmer and Edmond [1989] where Sr behaves conservatively with $\mathrm{Cl}$. However, samples at low $\mathrm{Cl}$ deviate from the linear correlation to higher $\mathrm{Sr}$ at a given $\mathrm{Cl}$ content forming a curved array. Additionally, samples from the Juan de Fuca ridge demonstrate that there are vents where the $\mathrm{Sr}$ concentration at a given $\mathrm{Cl}$ concentration is substantially higher than the curved trend defined by the majority of the data [Butterfield et al., 1994; Butterfield and Massoth, 1994]. Thus the mean $\mathrm{Sr}$ concentration of vent fluids is $\sim 40 \%$ higher than seawater consistent with the observation that $\mathrm{Sr}$ is leached from the sheeted dike complex during high-temperature alteration at the ridge axis.

\subsection{Regional Characteristics of Alteration}

\subsubsection{Comparable Alteration of Ocean Crust}

[26] The Sr-isotopic composition of the sheeted dike complex of modern oceanic crust formed at intermediate to fast spreading ridges shows remarkable similarity in the three areas that have been sampled to date (Figure 5). Sheeted dikes at Pito Deep have Sr isotopic compositions between 0.70252 and 0.70295 and dikes from Hess Deep range between 0.70257 and 0.70326 (Figure 5a) [Gillis et al., 2005]. The majority of sheeted dikes from ODP Hole 504B have a range of ${ }^{87} \mathrm{Sr} /{ }^{86} \mathrm{Sr}$ from 0.70257 to $0.70307,17 \%$ of sheeted dikes in the upper $450 \mathrm{~m}$ of the sheeted dike complex extend beyond this range to ${ }^{87} \mathrm{Sr} /{ }^{86} \mathrm{Sr}$ of 0.70535 but none of the deeper dikes have ${ }^{87} \mathrm{Sr} /{ }^{86} \mathrm{Sr}>$ 0.7031 (Figure 5b) [Bach et al., 2003; Teagle et al., 1998a, 1998b, 2003; Alt et al., 1996a, 1996b]. The mean ${ }^{87} \mathrm{Sr} /{ }^{86} \mathrm{Sr}$ with depth is similar for Pito Deep, Hess Deep and ODP Hole 504B and there is no statistically significant correlation of ${ }^{87} \mathrm{Sr} /{ }^{86} \mathrm{Sr}$ with depth in the sheeted dikes at Pito Deep, Hess Deep or ODP Hole 504B (Figures 5a and 5b). The observed similarity in $\mathrm{Sr}$ isotopic profiles through the sheeted dike complex exposed at three locations is important and surprising. This implies that sheeted dikes in young intermediate to fast spreading ocean crust at different locations with different initial $\mathrm{Sr}$ isotopic compositions (see section 5.2.2) are hydrothermally altered to the same narrow range in ${ }^{87} \mathrm{Sr} /{ }^{86} \mathrm{Sr}(0.7025$ to 0.7033$)$. This indicates that differences in spreading rate at intermediate to fast spreading ridges do not result in significant differences in the extent of ${ }^{87} \mathrm{Sr} /{ }^{86} \mathrm{Sr}$ exchange between hydrothermal fluid and ocean crust.

\subsubsection{Quantifying the Variability in ${ }^{87} \mathrm{Sr} /{ }^{86} \mathrm{Sr}$ in Altered Upper Oceanic Crust}

[27] To further investigate the striking similarity between the extent of $\mathrm{Sr}$-isotopic exchange between the sheeted dike complex and hydrothermal fluids in these three areas we compare the amount of fluid required to produce the observed Sr-isotopic modifications. The composition of the protolith in each of the three areas is slightly different, 


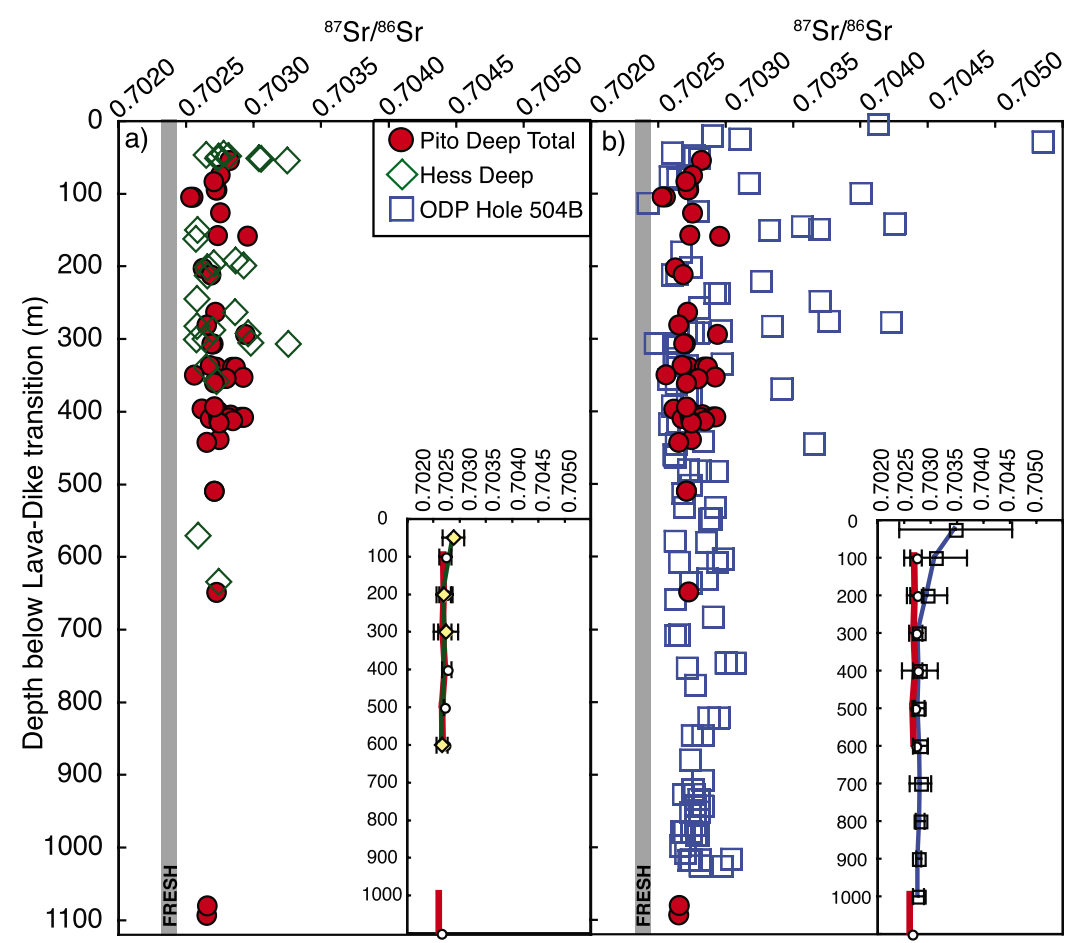

Figure 5. (a) Values of ${ }^{87} \mathrm{Sr} /{ }^{86} \mathrm{Sr}$ of sheeted dikes with depth for comparison of Pito Deep with Hess Deep. Inset shows mean ${ }^{87} \mathrm{Sr} /{ }^{86} \mathrm{Sr} \pm 1$ s.d. for sheeted dikes at $100 \mathrm{~m}$ depth intervals for Pito Deep (circles, red line) and Hess Deep (diamonds, green line). (b) Values of ${ }^{87} \mathrm{Sr} /{ }^{86} \mathrm{Sr}$ of sheeted dikes with depth for Pito Deep and ODP Hole 504B. Inset shows ${ }^{87} \mathrm{Sr} /{ }^{86} \mathrm{Sr}$ mean \pm 1 s.d. for sheeted dikes at $100 \mathrm{~m}$ depth intervals for Pito Deep (circles, red line) and ODP Hole 504B (squares, blue line). Data sources: Gillis et al. [2005], Bach et al. [2003], Teagle et al. [1998a, 1998b, 2003], Alt et al., 1996a, 1996b; Bickle and Teagle [1992].

therefore closed-system water-to-rock ratio (by mass) has been calculated for all samples to assess the relative alteration from fresh crust [e.g., Taylor, 1977]. Initial-rock Sr concentrations and Sr-isotopic compositions for dikes from all three areas are given in Table 1. We assume an initial fluid with $8 \mathrm{ppm} \mathrm{Sr}$ with an isotopic composition slightly modified (decreased by 0.0005 ) from seawater of the crustal age to account for exchange with basaltic $\mathrm{Sr}$ within the lava pile [Teagle et al., 2003]. The final fluid is assumed to have ${ }^{87} \mathrm{Sr} /{ }^{86} \mathrm{Sr}$ of 0.7038 to match average vent fluids. We assume here, and throughout, that $\mathrm{Sr}$ is not significantly taken up by anhydrite in the recharge zone depleting the fluid in Sr. If this assumption is invalid then the calculated fluid/rock ratios, and time-integrated fluid fluxes, will be underestimates.

[28] Fluid/rock ratios calculated assuming no change in the $\mathrm{Sr}$ concentration in either fluid or rock for the sheeted dike complex at Pito Deep range from 0.38 to 1.41 with a mean of $0.86 \pm 0.25$ (1 s.d.; Figure 6a). Sheeted dikes from Hess Deep have fluid/rock ratios of 0.24 to 1.97 , with mean of
$0.77 \pm 0.45$ ( 1 s.d.), while sheeted dikes from ODP Hole 504B have fluid/rock ratios of 0.20 to 4.73 with mean of $0.70 \pm 0.65$ (1 s.d.). Allowing sufficient Sr to be dissolved out of the rock into the fluid to increase the fluid $\mathrm{Sr}$ content to $11 \mathrm{ppm}$ (Figure 5) results in fluid/rock ratios that are higher by an average of $\sim 0.1$. All of the samples from all localities have fluid/rock ratios $\geq 0.20$, suggesting that all dikes have exchanged $\mathrm{Sr}$ with a hydrothermal fluid on a sample-scale (i.e., no areas greater than a few centimeters experience no fluid flow).

\subsubsection{Local Scale Variations at Pito Deep: Areas A and B}

[29] The sampling of two escarpments (Areas A and B) [Karson and Pito Deep Shipboard Scientific Party, 2005] at Pito Deep allows comparison of pervasive hydrothermal fluid flow in crustal sections approximately $20 \mathrm{~km}$ apart. Calculated fluid/ rock ratios for samples from Area B range from 0.64 to 1.38 with mean of $0.89 \pm 0.20$ ( 1 s.d.); samples from Area A are slightly more heterogeneously altered with fluid/rock ratios ranging from 


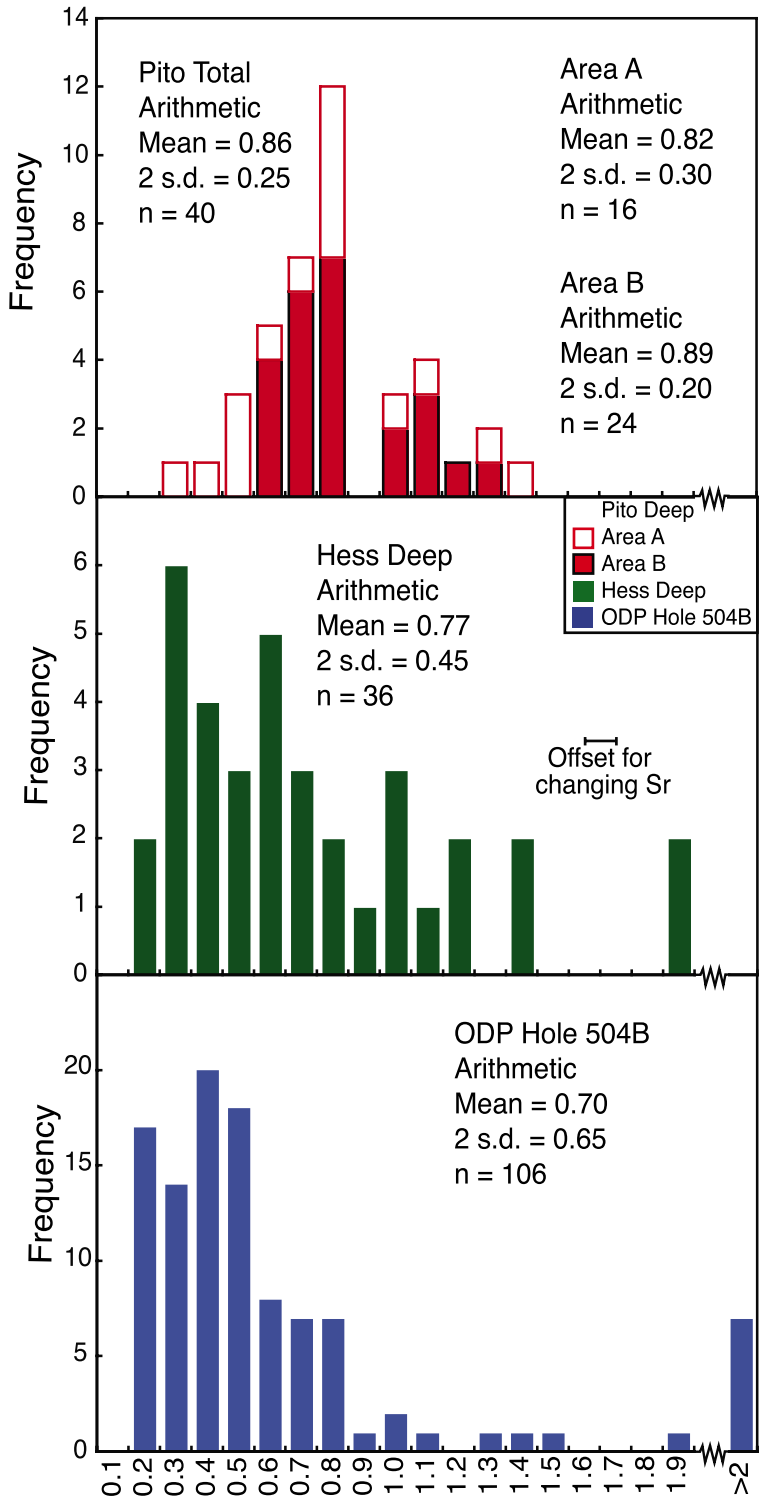

Fluid/rock

Figure 6. Histograms of closed system fluid/rock ratios for (a) Pito Deep, Areas A and B, (b) Hess Deep, and (c) ODP Hole 504B. Geometric mean for Pito Deep Total $=0.82$, Pito Deep Area $A=0.77$, Area $B=0.86$, Hess Deep $=0.66$, and ODP Hole 504B $=0.55$. Closed system fluid/rock ratios calculated from protolith of ${ }^{87} \mathrm{Sr} /{ }^{86} \mathrm{Sr}=0.70239, \mathrm{Sr}=95 \mathrm{ppm}$ at Pito Deep; Area A $\mathrm{Sr}=100 \mathrm{ppm}$, whereas Area $\mathrm{B} \mathrm{Sr}=95 \mathrm{ppm}$, with seawater of $8 \mathrm{ppm} \mathrm{Sr}$ and ${ }^{87} \mathrm{Sr} /{ }^{86} \mathrm{Sr}=0.7086$ and final vent fluid of $8 \mathrm{ppm} \mathrm{Sr}$ and ${ }^{87} \mathrm{Sr} /{ }^{86} \mathrm{Sr}=0.7038$. Hess Deep protolith has ${ }^{87} \mathrm{Sr} /{ }^{86} \mathrm{Sr}=0.70245$ with $\mathrm{Sr}=90 \mathrm{ppm}$ [Gillis et al., 2005], with seawater of $8 \mathrm{ppm} \mathrm{Sr}$ and ${ }^{87} \mathrm{Sr} /{ }^{86} \mathrm{Sr}=0.7086$ and final vent fluid of $8 \mathrm{ppm} \mathrm{Sr}$ and ${ }^{87} \mathrm{Sr} /{ }^{86} \mathrm{Sr}=0.7038$. ODP Hole $504 \mathrm{~B}$ protolith has ${ }^{87} \mathrm{Sr} /{ }^{86} \mathrm{Sr}=0.70245$ and $\mathrm{Sr}=60 \mathrm{ppm}$ [Schilling et al., 2003; Teagle et al., 1998a; Verma and Schilling, 1982], with seawater of $8 \mathrm{ppm} \mathrm{Sr}$ and ${ }^{87} \mathrm{Sr} /{ }^{86} \mathrm{Sr}=0.7084$ [Teagle et al., 2003] and final vent fluid of $8 \mathrm{ppm} \mathrm{Sr}$ and ${ }^{87} \mathrm{Sr} /{ }^{86} \mathrm{Sr}=0.7038$.
0.38 to 1.41 with a mean of $0.82 \pm 0.30$ ( 1 s.d.; Figure 6b).

\subsection{Estimating the Time-Integrated Fluid Flux}

[30] We use three approaches to model the timeintegrated fluid fluxes (in $\mathrm{kg}$ of fluid per $\mathrm{m}^{2}$ of crust) responsible for pervasive fluid flow in the sheeted dike complex at Pito Deep, Hess Deep and ODP Hole 504B: (1) mass balance of closed system fluid/rock ratios; (2) one-dimensional fluid-flow (recharge) over a vertical profile with kinetically limited isotopic exchange between fluid and rock; and (3) one-dimensional fluid-flow (recharge) over a vertical profile with diffusive exchange of Sr-isotopes between the rock and a fluid confined to cracks. The results suggest that the minimum time-integrated fluid fluxes for all areas lies between 1.5 and $2.6 \times 10^{6} \mathrm{~kg} \mathrm{~m}^{-2}$.

\subsubsection{Fluid-Rock Mass Balance}

[31] Time-integrated fluid fluxes $\left(\mathrm{kg} \mathrm{m}^{-2}\right)$ can be calculated from fluid/rock ratios by multiplying by the mass of rock per $\mathrm{m}^{2}$ column of crust. This depends on the thickness of the sheeted dike complex (1100 m at Pito Deep, $700 \mathrm{~m}$ at Hess Deep and $>1050 \mathrm{~m}$ at ODP Hole 504B [Karson et al., 2002; Karson and Pito Deep Shipboard Scientific Party, 2005; Alt et al., 1996a]) and density of basaltic dikes $\left(\sim 2.7 \mathrm{~kg} \mathrm{~m}^{-3}\right)$. The average closed system fluid/rock ratios for the sheeted dike complexes at Pito Deep, Hess Deep and ODP Hole 504B are 0.86, 0.77 and 0.70, respectively (Figure 6a). Resulting mean timeintegrated fluid fluxes are $2.6 \times 10^{6} \mathrm{~kg} \mathrm{~m}^{-2}$, $1.5 \times 10^{6} \mathrm{~kg} \mathrm{~m}^{-2}$ and $2.0 \times 10^{6} \mathrm{~kg} \mathrm{~m}^{-2}$, respectively (Table 2). Although samples from Hess Deep and Pito Deep have similar mean fluid/rock ratios, the sheeted dike complex is thinner at Hess Deep requiring a smaller fluid flux. If $\mathrm{Sr}$ loss from the rock to the fluid is included in the computation of the fluid/rock ratio (section 5.2.2) the time-integrated fluid flux is 0.2 to $0.4 \mathrm{~kg} \mathrm{~m}^{-2}$ higher.

\subsubsection{Depth-Constrained Isotopic Exchange During Recharge: A Linear Kinetic Approximation}

[32] The time-integrated fluid fluxes calculated in the previous section provide useful constraints on the amount of fluid that reacted with the sheeted dike complex. It is generally assumed that the reaction of fluid and rock occurs during recharge of the hydrothermal system [e.g., Teagle et al., 
Table 2. Estimated Fluid Fluxes for Pito Deep, Hess Deep, and ODP Hole 504B

\begin{tabular}{|c|c|c|c|c|c|}
\hline \multirow[b]{2}{*}{ Model $^{\mathrm{a}}$} & \multirow[b]{2}{*}{ Pito Deep } & \multirow[b]{2}{*}{ Hess Deep } & \multirow[b]{2}{*}{ 504B } & \multicolumn{2}{|c|}{ Pito Deep } \\
\hline & & & & Area A & Area B \\
\hline $\begin{array}{l}\text { Fluid/rock mass } \\
\text { balance }\end{array}$ & $2.6 \times 10^{6}$ & $1.5 \times 10^{6}$ & $2.0 \times 10^{6}$ & $2.4 \times 10^{6}$ & $2.6 \times 10^{6}$ \\
\hline Uncertainty & $\pm 0.9 \times 10^{6}$ & $\pm 0.9 \times 10^{6}$ & $\pm 0.6 \times 10^{6}$ & $\pm 0.3 \times 10^{6}$ & $\pm 0.6 \times 10^{6}$ \\
\hline $\begin{array}{l}\text { Linear kinetics } \\
\text { approximation }^{\mathrm{b}}\end{array}$ & $2.4 \times 10^{6}(0.1)$ & $1.04 \times 10^{6}(0.1)$ & $2.1 \times 10^{6}(0.1)$ & $2.2 \times 10^{6}(0.1)$ & $2.3 \times 10^{6}(0.1)$ \\
\hline $\begin{array}{l}\text { Standard error of } \\
\text { best fit }\end{array}$ & $4.6 \times 10^{-8}$ & $9.5 \times 10^{-5}$ & $3.9 \times 10^{-4}$ & $4.7 \times 10^{-8}$ & $3.4 \times 10^{-8}$ \\
\hline $\begin{array}{c}\text { Predicted }{ }^{87} \mathrm{Sr} /{ }^{86} \mathrm{Sr} \\
\text { of basal fluid }\end{array}$ & 0.7040 & 0.7034 & 0.7040 & 0.7044 & 0.7039 \\
\hline Published fluid flux & & $3.2 \times 10^{6}(0.07)$ & $1.7 \times 10^{6}(0.2) ; 5 \times 10^{6}(1)$ & & \\
\hline Reference & & $\begin{array}{l}\text { Gillis et al. } \\
\text { [2005] }\end{array}$ & $\begin{array}{c}\text { Teagle et al. [2003]; } \\
\text { Bickle and Teagle [1992] }\end{array}$ & & \\
\hline $\begin{array}{l}\text { Diffusive exchange } \\
\text { around a "single } \\
\text { crack"b }\end{array}$ & $5.4 \times 10^{6}(0.13)$ & $3.6 \times 10^{6}(0.09)$ & $6.4 \times 10^{6}(0.15)$ & $4.6 \times 10^{6}(0.12)$ & $5.8 \times 10^{6}(0.14)$ \\
\hline $\begin{array}{l}\text { Standard error of } \\
\text { best fit }\end{array}$ & $4.4 \times 10^{-9}$ & $8.2 \times 10^{-9}$ & $3.1 \times 10^{-4}$ & $2.7 \times 10^{-8}$ & $3.3 \times 10^{-9}$ \\
\hline $\begin{array}{l}\text { Predicted }{ }^{87} \mathrm{Sr} /{ }^{86} \mathrm{Sr} \\
\text { of basal fluid }\end{array}$ & 0.7072 & 0.7074 & 0.7076 & 0.7070 & 0.7072 \\
\hline
\end{tabular}

${ }^{a}$ Fluid fluxes are in $\mathrm{kg} \mathrm{m}^{-2}$. Model input parameters: densities of $2.7 \mathrm{~kg} \mathrm{~m}^{-3}$ and $1 \mathrm{~kg} \mathrm{~m}^{-3}$ in rock and seawater, respectively, porosity of $0.02 \mathrm{~kg} \mathrm{~m}^{-3}$. Location-specific parameters for ODP Hole 504B; seawater Sr concentration of $8 \mathrm{ppm}$, with modified ${ }^{87} \mathrm{Sr} /{ }^{86} \mathrm{Sr}$ of 0.7084 due to reaction with lava pile for ODP Hole 504B [Teagle et al., 2003], initial Sr concentrations of sheeted dike complex are $60 \mathrm{ppm},{ }^{87} \mathrm{Sr}{ }^{86} \mathrm{Sr}$ of fresh rock is 0.70245 [Verma and Schilling, 1982; Schilling et al., 2003]. Pito Deep has seawater Sr concentration of 8 ppm and ${ }^{87} \mathrm{Sr}{ }^{86} \mathrm{Sr} 0.7086$, initial Sr concentrations of sheeted dike complex are $95 \mathrm{ppm}\left(100 \mathrm{ppm}\right.$ for Area A and $95 \mathrm{ppm}$ for Area B), and ${ }^{87} \mathrm{Sr} /{ }^{86} \mathrm{Sr}$ of fresh rock is 0.70239 . Hess Deep has seawater $\mathrm{Sr}$ concentration of $8 \mathrm{ppm}$ and ${ }^{87} \mathrm{Sr}{ }^{86} \mathrm{Sr} 0.7086$, initial $\mathrm{Sr}$ concentrations of sheeted dike complex are $90 \mathrm{ppm},{ }^{\mathrm{and}}{ }^{87} \mathrm{Sr} /{ }^{86} \mathrm{Sr}$ of fresh rock is 0.70245 [Gillis et al., 2005; this study].

${ }^{\mathrm{b}}$ Damköhler number used is given in parentheses.

2003]. If this is true the rock ${ }^{87} \mathrm{Sr} /{ }^{86} \mathrm{Sr}$ should vary systematically with depth in the crust because as a hydrothermal fluid passes through the crust it will progressively equilibrate with the crust and lead to progressively smaller changes in the rock composition. Thus the variation in extent of alteration with depth provides further information about the process of fluid-rock reaction. This kind of onedimensional fluid flow has been modeled for the oceanic crust under the assumption of kinetically hindered fluid-rock equilibration [Bickle and Teagle, 1992; Teagle et al., 2003]. We follow this approach here using the model of Bickle [1992; cf. Blattner and Lassey, 1989] in which the rate of exchange of Sr-isotopes between the fluid and rock is assumed to be linearly proportional to the difference in ${ }^{87} \mathrm{Sr} /{ }^{86} \mathrm{Sr}$ between the rock and fluid at all depths in the system (i.e., linear kinetics). The concentration of $\mathrm{Sr}$ in the fluid and rock are assumed fixed in this model. In this linear kinetic model the relative rates of advection of $\mathrm{Sr}$ through the system by the fluid versus Sr-isotope exchange with the wall rock is controlled by a dimensionless
Damköhler number $\left(\mathrm{N}_{\mathrm{D}}\right)$, with the $\mathrm{N}_{\mathrm{D}}$ increasing with increasing exchange rate.

[33] Since this linear kinetic model includes mass balance, if the fluid at the base of the system is fixed to equal the vent fluid composition, assuming no fluid-rock reaction during discharge, identical time-integrated fluid fluxes are computed using this model as using the fluid/rock ratio. As an alternative approach to modeling the fluid flux we ignore the vent fluid composition and fit the rock data using this model. Using the same input parameters as previous studies (rock density is $2.7 \mathrm{~kg} \mathrm{~m}^{-3}$; fluid density is $1 \mathrm{~kg} \mathrm{~m}^{-3}$ [e.g., Teagle et al., 2003]) the lack of significant variation in rock ${ }^{87} \mathrm{Sr} /{ }^{86} \mathrm{Sr}$ with depth requires a slow rate of $\mathrm{Sr}$ isotope exchange that is approximated by a $\mathrm{N}_{\mathrm{D}}=$ 0.1 . We kept this constant in all model runs for two reasons. First the lack of significant variation in the rock composition with depth in the crust means that the rock ${ }^{87} \mathrm{Sr} /{ }^{86} \mathrm{Sr}$ provides a poor constraint on this parameter. Second, keeping this value constant facilitates comparison of the time-integrated fluid fluxes between locations. The best fit of the model to the data was assessed by minimization 


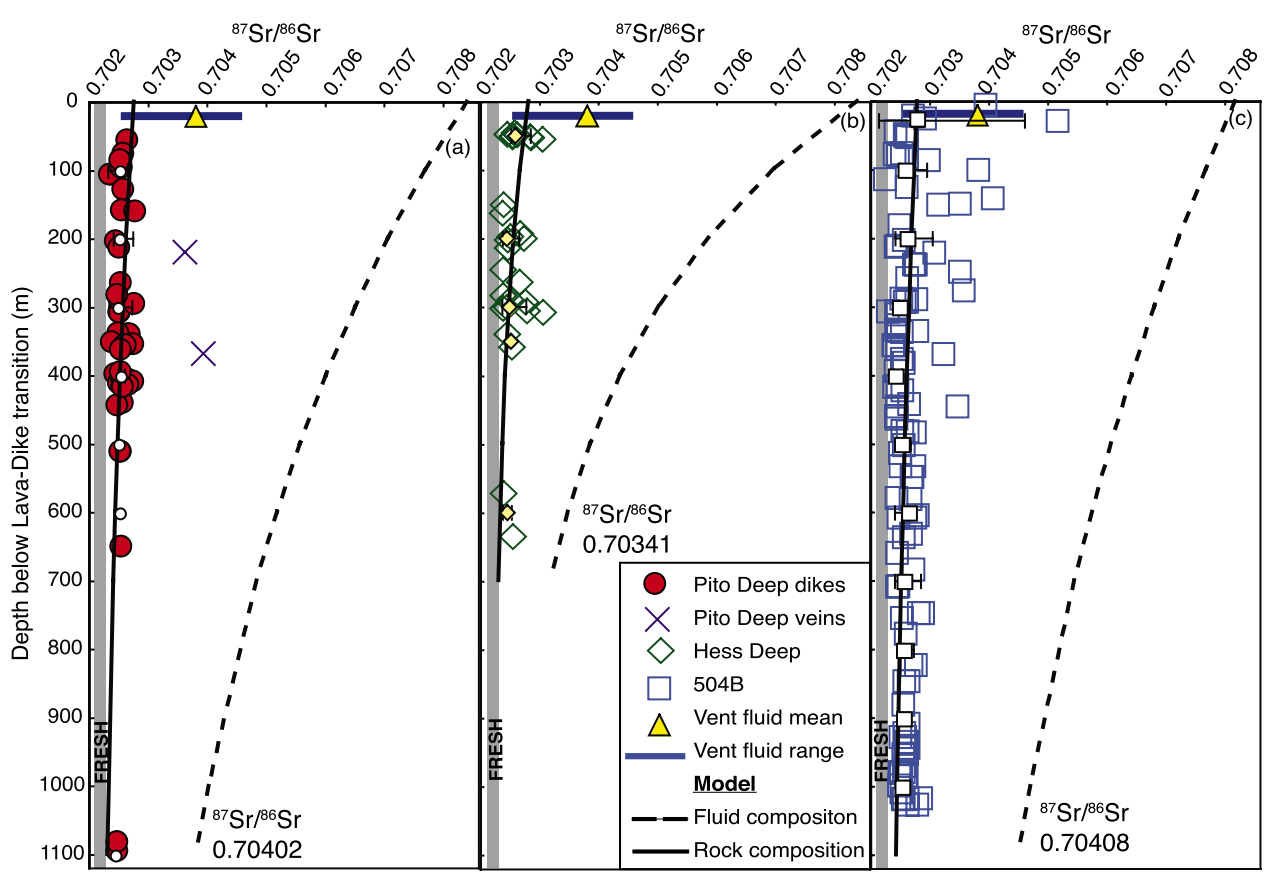

Figure 7. Linear kinetic model for fluid fluxes through sheeted dike complexes at (a) Pito Deep data with median \pm 95\% confidence interval for $100 \mathrm{~m}$ depth intervals, (b) Hess Deep with median $\pm 95 \%$ confidence interval for $100 \mathrm{~m}$ depth intervals, and (c) ODP Hole 504B with median $\pm 95 \%$ confidence interval for $100 \mathrm{~m}$ depth intervals. Model input parameters: $\mathrm{N}_{\mathrm{D}}=0.1$ in all locations, densities of $2.7 \mathrm{~kg} \mathrm{~m}^{-3}$ and $1 \mathrm{~kg} \mathrm{~m}^{-3}$ in rock and seawater, respectively [Teagle et al., 2003], porosity of $0.02 \mathrm{~kg} \mathrm{~m}^{-3}$. Location-specific parameters for ODP Hole 504B; seawater $\mathrm{Sr}$ concentration of $8 \mathrm{ppm}$, with modified ${ }^{87} \mathrm{Sr} /{ }^{86} \mathrm{Sr}$ of 0.7084 due to reaction with lava pile for ODP Hole 504B [Teagle et al., 2003]. Initial Sr concentrations of sheeted dike complex are $60 \mathrm{ppm} ;{ }^{87} \mathrm{Sr} /{ }^{86} \mathrm{Sr}$ of fresh rock is 0.70245 [Verma and Schilling, 1982; Schilling et al., 2003]. Pito Deep has seawater Sr concentration of 8 ppm and ${ }^{87} \mathrm{Sr} /{ }^{86} \mathrm{Sr} 0.7086$, initial $\mathrm{Sr}$ concentrations of sheeted dike complex are $95 \mathrm{ppm}$ (100 ppm for Area A and $95 \mathrm{ppm}$ for Area B), and ${ }^{87} \mathrm{Sr}{ }^{86} \mathrm{Sr}$ of fresh rock is 0.70239 . Hess Deep has seawater $\mathrm{Sr}$ concentration of $8 \mathrm{ppm}$ and ${ }^{87} \mathrm{Sr} /{ }^{86} \mathrm{Sr} 0.7086$, initial $\mathrm{Sr}$ concentrations of sheeted dike complex are $90 \mathrm{ppm}$, and ${ }^{87} \mathrm{Sr} /{ }^{86} \mathrm{Sr}$ of fresh rock is 0.70245 [Gillis et al., 2005; this study]. Final fluid at base of sheeted dike complex is assumed to discharge without further modification to form vent fluids. Calculated final fluid compositions are within the range of ${ }^{87} \mathrm{Sr} /{ }^{86} \mathrm{Sr}$ for vent fluids and the ${ }^{87} \mathrm{Sr} /{ }^{86} \mathrm{Sr}$ composition of quartz-epidote veins at Pito Deep and ODP Hole 504B.

of the standard error of difference between the model and the median rock ${ }^{87} \mathrm{Sr} /{ }^{86} \mathrm{Sr}$ at $100 \mathrm{~m}$ depth intervals. The median was chosen to lessen the bias toward outliers observed at high ${ }^{87} \mathrm{Sr} /{ }^{86} \mathrm{Sr}$, especially at ODP Hole 504B.

[34] Using this approach, the time-integrated fluid fluxes calculated for Pito Deep and ODP Hole 504B are similar to those calculated using the closed-system fluid/rock ratio (Figure 7 and Table 2). The calculated ${ }^{87} \mathrm{Sr} /{ }^{86} \mathrm{Sr}$ for the fluid at the base of the system is comparable to vent fluids from the East Pacific and quartz-epidote veins from Pito Deep and ODP Hole 504B. The fluid flux calculated using this approach for the sheeted dike complex at Hess Deep is slightly lower than that calculated using a closed system fluid/rock ratio because the resulting fluid has a lower ${ }^{87} \mathrm{Sr} /{ }^{86} \mathrm{Sr}$ than the average vent fluid (Figure 7). As discussed above, leaching of Sr from the sheeted dikes can lower the ${ }^{87} \mathrm{Sr} /{ }^{86} \mathrm{Sr}$ of resulting fluid compositions meaning that the computed fluid ${ }^{87} \mathrm{Sr} /{ }^{86} \mathrm{Sr}$ in all of these models are maximums.

[35] Our estimate for time-integrated fluid fluxes in the sheeted dike complex at ODP Hole 504B is similar to the fluid flux calculated using a $\mathrm{N}_{\mathrm{D}}$ of 0.2 and fitting the model fluid ${ }^{87} \mathrm{Sr} /{ }^{86} \mathrm{Sr}$ to the measured ${ }^{87} \mathrm{Sr} /{ }^{86} \mathrm{Sr}$ of anhydrite assuming these anhydrite formed in equilibrium with recharging fluids [Teagle et al., 2003]. The difference between the estimated fluid flux for Hess Deep and the published value [Gillis et al., 2005] is due to the higher exchange rate $\left(\mathrm{N}_{\mathrm{D}}\right)$ used here.

[36] The misfit between the models and data provides insight into whether Sr-isotope exchange occurs solely during recharge as assumed in this 


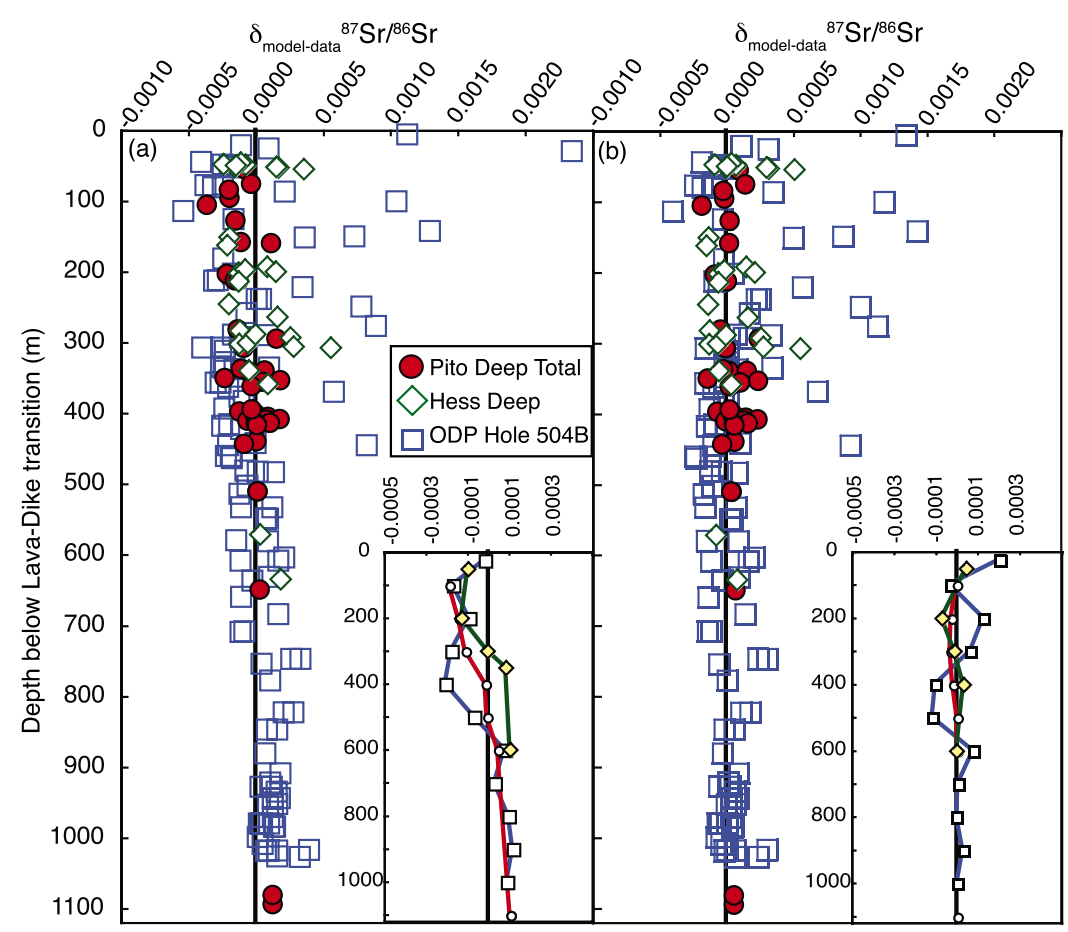

Figure 8. Deviation between samples and model curves for sheeted dikes at Pito Deep, Hess Deep, and ODP Hole 504B. (a) Linear kinetic model $\mathrm{N}_{\mathrm{D}}=0.1$. Inset shows deviations between median and the linear kinetic model for 100 $m$ depth intervals. (b) Single crack model. Inset shows deviations between median and the single crack model for 100 $m$ depth intervals.

modeling. If the misfits were randomly distributed with depth then this model would be consistent with the data but this is not the case (Figure 8a). At Pito Deep the rocks are, on average, less altered than the model predicts in the top $250 \mathrm{~m}$ of the sheeted dikes and more altered than the model predicts at the very base of the sheeted dike complex. Unfortunately we have few samples from the base of the sheeted dike complex adding to the uncertainty in this conclusion. For Hess Deep the smaller depth range of sampling, and the paucity of samples from deep in the sheeted dike complex, makes it even more difficult to determine how well the model fits the data. The model fits the data reasonably well in the upper portion of the sheeted dike complex but samples from the base of the sheeted dike complex have higher ${ }^{87} \mathrm{Sr} /{ }^{86} \mathrm{Sr}$ than predicted by the model. The much larger data set, especially in the deeper dikes, for ODP Hole 504B allows much more rigorous testing of the model. For this sample suite the upper dikes are less altered than the model predicts and the deeper dikes are more altered than the model predicts (Figure 8a). Using a $\mathrm{N}_{\mathrm{D}}$ of 0.2 to model the data from ODP Hole 504B as proposed by Teagle et al. [2003] accentuates these systematic misfits. These systematic misfits suggest that the basic premise of this model, that fluid-rock reaction occurs homogeneously during one-dimensional fluid transport, is not valid.

[37] One assumption of the modeling presented in Figure 7 is that the rate of Sr-isotopic exchange between the fluid and rock is assumed simply to be linearly proportional to the difference in fluid and rock ${ }^{87} \mathrm{Sr} /{ }^{86} \mathrm{Sr}$ ratio. A more realistic model might be diffusive exchange of $\mathrm{Sr}$ from fluid filled cracks into the wall rock. Bickle [1992] shows that for high $\mathrm{N}_{\mathrm{D}}$, the linear kinetic and diffusive models give the same result but at low $\mathrm{N}_{\mathrm{D}}(<1)$ the effect on the rock composition is significantly different. To test whether this can explain the misfit between the model and data we apply this model in the following section.

\subsubsection{Low Rates of Fluid-Rock Reaction: Diffusive Exchange Around a "Single Crack"}

[38] If the fluid-rock reaction process leads to the rate of $\mathrm{Sr}$ exchange not being linearly dependent on the difference in ${ }^{87} \mathrm{Sr} /{ }^{86} \mathrm{Sr}$ between the rock and fluid, but instead being slower, this could potentially explain the lack of any systematic change in 


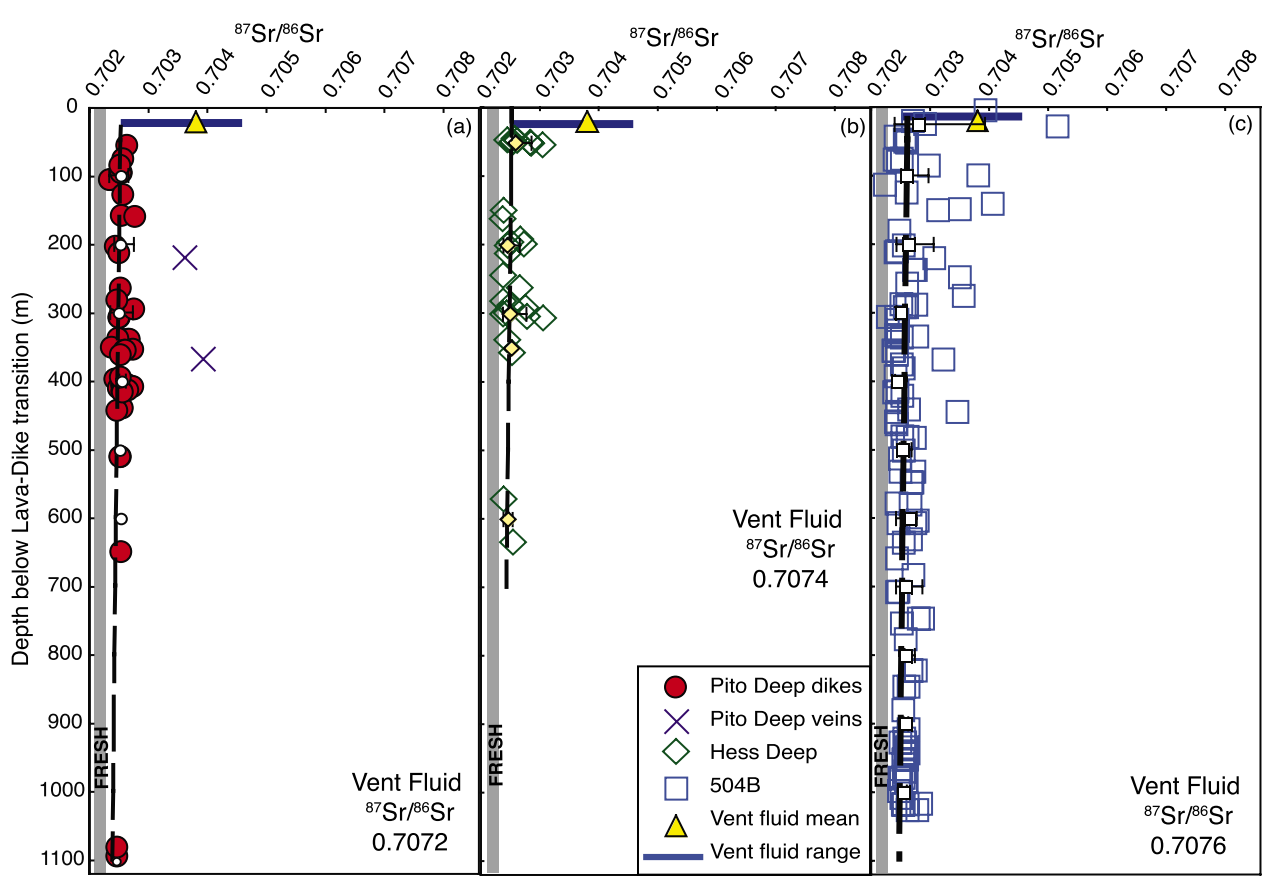

Figure 9. Single crack model of fluid flux at (a) Pito Deep with data for the sheeted dikes and median $\pm 95 \%$ confidence interval for $100 \mathrm{~m}$ depth intervals, (b) Hess Deep with data for the sheeted dikes and median $\pm 95 \%$ confidence interval for $100 \mathrm{~m}$ depth intervals, and (c) ODP Hole 504B with data for the sheeted dikes and median \pm $95 \%$ confidence interval for $100 \mathrm{~m}$ depth intervals. See Table 2 for $\mathrm{N}_{\mathrm{D}}$ and fluid fluxes.

rock composition with depth. An example of this kind of exchange mechanism is if fluid-rock reaction occurs around fractures where the alteration haloes around these fractures do not overlap. Tang et al. [1981] present an analytical solution to the equations describing the concentration of a tracer in the wall rock around a fracture through which fluid flows (i.e., fluid flow perpendicular to Srexchange). Bickle [1992] integrated this to obtain a solution (his equation (38)) for the average rock composition as a function of a $\mathrm{N}_{\mathrm{D}}$ equivalent to that discussed above. Bickle [1992] suggests that this model is more appropriate for tracing fluid flow when the fluid-rock exchange rates are low $\left(\mathrm{N}_{\mathrm{D}}<0.3\right)$. We have modeled the variation in ${ }^{87} \mathrm{Sr} /{ }^{86} \mathrm{Sr}$ in the sheeted dikes with depth below the lava-sheeted dike transition in this way for all three areas. We allow the $\mathrm{N}_{\mathrm{D}}$ to vary as well as the fluid flux and calculated best fitting fluid fluxes and $\mathrm{N}_{\mathrm{D}}$ (in parentheses) of $5.4 \times 10^{6} \mathrm{~kg} \mathrm{~m}^{-2}$ $(0.13), 3.6 \times 10^{6} \mathrm{~kg} \mathrm{~m}^{-2}(0.09)$ and $6.4 \times$ $10^{6} \mathrm{~kg} \mathrm{~m}^{-2}(0.15)$ for Pito Deep, Hess Deep and ODP Hole 504B, respectively (Figure 9 and Table 2).

[39] These models fit the data better than the models presented above with little systematic change in the misfit between the model and data with depth in the sheeted dike complex (Figure 8b).
However, the fluid fluxes calculated using this approach are significantly greater than those calculated above leading to the fluid becoming less rock-dominated. The fluid ${ }^{87} \mathrm{Sr} /{ }^{86} \mathrm{Sr}$ at the base of the system can be calculated by mass balance to be between 0.7070 and 0.7076 , substantially higher than vent fluids. Assuming these final fluid compositions are vented without further modification during discharge they are far too high in ${ }^{87} \mathrm{Sr} /{ }^{86} \mathrm{Sr}$ for this model to provide an accurate representation of the behavior of $\mathrm{Sr}$ in the axial hydrothermal system. Even leaching a small amount of Sr from the crust (Figures 4 and 5) cannot bring the fluid ${ }^{87} \mathrm{Sr} /{ }^{86} \mathrm{Sr}$ down to the range of vent fluids. Thus, unless there is a region of the crust from which $\mathrm{Sr}$ is leached substantially more than from any observed samples this model appears unsatisfactory.

\subsection{Fluid-Rock Reaction During Discharge as Well as Recharge?}

[40] Since neither pervasive, kinetically inhibited, fluid-rock reaction nor fluid-rock reaction around isolated channels appears to fit both the variation in rock composition with depth and the vent fluids compositions, we consider a third model in which fluid-rock reaction occurs during both recharge and discharge. This might be expected since the fluid is 


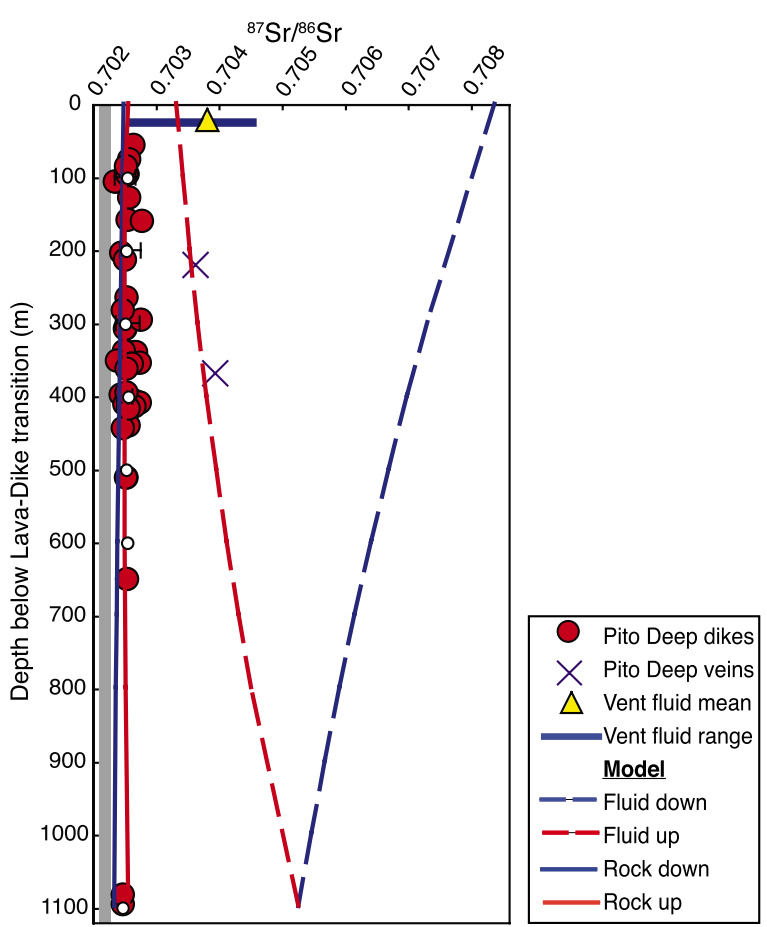

Figure 10. Downwelling and upwelling of fluid modeled by linear kinetic exchange for sheeted dikes at Pito Deep with median $\pm 95 \%$ confidence interval for $100 \mathrm{~m}$ depth intervals.

likely to be more reactive once it is heated near the base of the system [e.g., Fontaine and Wilcock, 2007; Coogan, 2008]. Because this model has more free parameters our aim is not to fit the data perfectly but rather to test whether the model is broadly consistent with the data. We use a pervasive flow model with kinetically limited exchange (linear kinetics) and assume that recharge and discharge of the fluid occur over the same part of the sheeted dike complex. Realistically, recharge and discharge would be expected to occur at different times in the axial history of the ocean crust, with recirculating hydrothermal fluids potentially affecting any profile of the ocean crust multiple times [Fontaine and Wilcock, 2007]. The model is constructed in two parts with the resulting fluid and rock $\mathrm{Sr}$ isotopic compositions from the recharging leg providing input parameters for the discharging leg and alteration of the sheeted dike complex occurring during discharge being additive to that accrued during recharge. On the basis of the idea that the upflowing fluid will be hotter and hence exchange isotopes with the crust more rapidly we use a $\mathrm{N}_{\mathrm{D}}=0.05$ in the recharge zone and $\mathrm{N}_{\mathrm{D}}=0.08$ in the upflow zone. Fitting the data from Pito Deep (Figure 10) using a similar fluid flux as in the unidirectional linear-kinetic model gives a vent fluid of ${ }^{87} \mathrm{Sr} /{ }^{86} \mathrm{Sr} 0.70352$ and matches the ${ }^{87} \mathrm{Sr} /{ }^{86} \mathrm{Sr}$ of vein hosted epidote at 220 and $370 \mathrm{~m}$, that are assumed to have formed from discharging fluids. This modeling demonstrates that if fluidrock reaction occurs within the regions of upflow in addition to those of downflow there is no requirement for there to be any variation of ${ }^{87} \mathrm{Sr} /{ }^{86} \mathrm{Sr}$ with depth in the sheeted dike complex unlike if reaction occurs only in the recharge zone.

[41] Thus far, limited ${ }^{87} \mathrm{Sr} /{ }^{86} \mathrm{Sr}$ data for fluid derived hydrothermal minerals (0.7034-0.7041 [Teagle et al., 1998b; this study]) indicate precipitation from highly evolved fluids that would be expected to be associated with hot reactive fluids deep in the hydrothermal system or upflow zones analogous to the discharging leg of this model. There is no clear evidence for reaction during recharge of cooler fluids, perhaps due to limited fluid-rock reaction or overprinting.

\section{Discussion and Conclusions}

[42] There are three important conclusions from this study:

[43] 1. The remarkable similarity in the Sr-isotope profile recorded by the sheeted dike complex in three different areas suggests that fluid flow through the sheeted dike complex is surprisingly uniform. This is despite significant differences in the spreading rate and thickness of the sheeted dike complex. Additionally there are differences in the protolith composition, in particular plagioclase An-content, which might be expected to lead to difference in the reactivity of the crust but do not appear to be important (Table 1). Neither does the extent of mineralogical alteration or dominant secondary phase appear critical (Table 1).

[44] 2. The modification of the ${ }^{87} \mathrm{Sr} /{ }^{86} \mathrm{Sr}$ in both the sheeted dike complex and vent fluids are consistent with minimum fluid fluxes through the sheeted dike complex at intermediate to fast spreading ridges of between 1.5 and $2.6 \times 10^{6} \mathrm{~kg} \mathrm{~m}^{-2}$. Evidence for leaching of $\mathrm{Sr}$ from the crust into the hydrothermal fluid means that this is an underestimate of the true flux by between $\sim 0.2$ and $0.4 \mathrm{~kg}$ $\mathrm{m}^{-2}$. These fluxes ignore two potentially important factors. First, if significant anhydrite is precipitated in the recharge zone this could deplete the recharging fluid of Sr leading to a higher fluid flux being required for a given change in rock composition. Second, if a substantial portion of the fluid flux 
through the axial system is channelized this will not be recorded by the samples studied.

[45] 3. The lack of a significant change in the ${ }^{87} \mathrm{Sr} /{ }^{86} \mathrm{Sr}$ of samples from the sheeted dike complex with depth in the crust is inconsistent with all Sr-isotope exchange occurring within a recharge zone. This can be explained if fluid-rock reaction also occurs within the discharge zone.

\section{Acknowledgments}

[46] Journal reviews from Damon Teagle and Mike Bickle are gratefully acknowledged. We would like to thank Jeff Karson and Emily Klein for the opportunity to work on the Pito Deep project. We are grateful to Jody Spence at the University of Victoria and Bruno Kieffer at the Pacific Centre for Isotopic and Geochemical Research, University of British Columbia, for analytical assistance and Mike Bickle and Nick Hayman for discussion. We thank the Pito Deep shipboard scientific party for collecting and logging samples and acknowledge NSF grant OCE-0222154 to J. A. Karson and E. M. Klein that funded the cruise. Postcruise science was funded through the NSERC SRO program.

\section{References}

Albarède, F., A. Michard, J. F. Minster, and G. Michard (1981), ${ }^{87} \mathrm{Sr} /{ }^{86} \mathrm{Sr}$ ratios in hydrothermal waters and deposits from the East Pacific Rise at $21^{\circ} \mathrm{N}$, Earth Planet. Sci. Lett., 55(2), 229-236, doi:10.1016/0012-821X(81)90102-3.

Alt, J. C. (1995). Subseafloor processes in mid-ocean ridge hydrothermal systems, in Seafloor Hydrothermal Systems: Physical, Chemical, Biological and Geological Interactions, Geophys. Monogr. Ser., vol. 91, edited by S. E. Humphris et al., pp. 85-114, AGU, Washington, D.C.

Alt, J. C., T. F. Anderson, L. Bonnell, and K. Muehlenbachs (1989), Mineralogy, chemistry and stable isotope compositions of hydrothermally altered sheeted dikes: ODP Hole 504B, Leg 111, Proc. Ocean Drill. Program Sci. Results, $111,27-40$.

Alt, J. C., D. A. H. Teagle, W. Bach, A. N. Halliday, and J. Erzinger (1996a), Stable and strontium isotopic profiles through hydrothermally altered upper oceanic crust, Hole 504B, Proc. Ocean Drill. Program Sci. Results, 148, 57-69.

Alt, J. C., C. Laverne, D. Vanko, P. Tartarotti, D. A. H. Teagle, W. Bach, E. Zulegar, J. Erzinger, and J. Honnorez (1996b), Hydrothermal alteration of a section of upper oceanic crust in the eastern equatorial Pacific: A synthesis of results from DSDP/ODP Legs 69, 70, 83, 111, 137, 140, 148 at Site 504B, Proc. Ocean Drill. Program Sci. Results, 148, $417-$ 434.

Bach, W., and S. E. Humphris (1999), Relationship between the $\mathrm{Sr}$ and $\mathrm{O}$ isotope compositions of hydrothermal fluids and the spreading and magma-supply rates at oceanic spreading centers, Geology, 27, 1067-1070, doi:10.1130/00917613(1999)027<1067:RBTSAO >2.3.CO;2.

Bach, W., B. Peucker-Ehrenbrink, S. R. Hart, and J. S. Blusztajn (2003), Geochemistry of hydrothermally altered oceanic crust: DSDP/ODP Hole 504B - Implications for seawater-crust exchange budgets and $\mathrm{Sr}$ - and $\mathrm{Pb}$-isotopic evolution of the man- tle, Geochem. Geophys. Geosyst., 4(3), 8904, doi:10.1029/ 2002GC000419.

Bau, M. (1991), Rare-earth element mobility during hydrothermal and metamorphic fluid-rock interaction and the significance of the oxidation state of europium, Chem. Geol., 93, 219-230, doi:10.1016/0009-2541(91)90115-8.

Berndt, M. E., W. E. Seyfried, and J. W. Beck (1988), Hydrothermal alteration processes at midocean ridges: Experimental and theoretical constraints from $\mathrm{Ca}$ and $\mathrm{Sr}$ exchange reactions and $\mathrm{Sr}$ isotopic ratios, J. Geophys. Res., 93(B5), 4573-4583, doi:10.1029/JB093iB05p04573.

Bickle, M. J. (1992), Transport mechanisms by fluid-flow in metamorphic rocks: Oxygen and strontium decoupling in the Trois Seigneurs massif-A consequence of kinetic dispersion?, Am. J. Sci., 292, 289-316.

Bickle, M. J., and D. A. H. Teagle (1992), Strontium alteration in the Troodos ophiolite: Implications for fluid fluxes and geochemical transport in mid-ocean ridge hydrothermal systemsEarth Planet. Sci. Lett., 113, 219-237, doi:10.1016/ 0012-821X(92)90221-G.

Bickle, M. J., D. A. H. Teagle, J. Beynon, and H. J. Chapman (1998), The structure and controls on fluid-rock interactions in ocean ridge hydrothermal systems: Constraints from the Troodos ophiolite, in Modern Ocean Floor Processes and the Geological Record, edited by R. A. Mills and K. Harrison, Geol. Soc. Spec. Publ., 148, 127-152.

Blattner, P., and K. Lassey (1989), Stable-isotope exchange fronts, Damköhler numbers, and fluid to rock ratios, Chem. Geol., 78, 381-392, doi:10.1016/0009-2541(89)90070-3.

Butterfield, D. A., and G. J. Massoth (1994), Geochemistry of north Cleft segment vent fluids: Temporal changes in chlorinity and their possible relation to recent volcanism, J. Geophys. Res., 99(B3), 4951-4968, doi:10.1029/93JB02798.

Butterfield, D. A., R. E. McDuff, M. J. Mottl, M. D. Lilley, J. E. Lupton, and G. J. Massoth (1994), Gradients in the composition of hydrothermal fluids from the Endeavour segment vent field: Phase separation and brine loss, J. Geophys. Res., 99(B5), 9561-9583, doi:10.1029/93JB03132.

Charlou, J. L., Y. Fouquet, J. P. Danval, and J. M. Auzende (1996), Mineral and gas chemistry of hydrothermal fluids on an ultrafast spreading ridge: East Pacific Rise, $17^{\circ}$ to $19^{\circ} \mathrm{S}$ (Naudar cruise, 1993) phase separation processes controlled by volcanic and tectonic activity, J. Geophys. Res., 101(B7), 15,899-15,919, doi:10.1029/96JB00880.

Coogan, L. A. (2008), Reconciling temperatures of metamorphism, fluid fluxes, and heat transport in the upper crust at intermediate to fast spreading mid-ocean ridges, Geochem. Geophys. Geosyst., 9, Q02013, doi:10.1029/2007GC001787.

Coogan, L. A., K. M. Gillis, C. J. MacLeod, G. M. Thompson, and R. Hékinian (2002), Petrology and geochemistry of the lower ocean crust formed at the East Pacific Rise and exposed at Hess Deep: A synthesis and new results, Geochem. Geophys. Geosyst., 3(11), 8604, doi:10.1029/ 2001GC000230.

Davis, A. C., M. J. Bickle, and D. A. H. Teagle (2003), Imbalance in the oceanic strontium budget, Earth Planet. Sci. Lett., 211, 173-187, doi:10.1016/S0012-821X(03)00191-2.

Eggins, S. M., J. D. Woodhead, L. P. J. Kinsley, G. E. Mortimer, P. Sylvester, M. T. McCulloch, J. M. Hergt, and M. R. Handler (1997), A simple method for the precise determination of $\geq 40$ trace elements in geological samples by ICPMS using enriched isotope internal standardization, Chem. Geol., 134, 311-326, doi:10.1016/S0009-2541(96)00100-3.

Fontaine, F. J., and W. S. D. Wilcock (2007), Two-dimensional numerical models of open-top hydrothermal convection at high Rayleigh and Nusselt numbers: Implications for mid- 
ocean ridge hydrothermal circulation, Geochem. Geophys. Geosyst., 8, Q07010, doi:10.1029/2007GC001601.

Francheteau, J., P. Patriat, J. Segoufin, R. Armijo, M. Doucoure, A. Yelles-Chaouche, J. Zukin, S. Calmant, D. F. Naar, and R. C. Searle (1988), Pito and Orongo fracture zones: The northern and southern boundaries of the Easter microplate (southeast Pacific), Earth Planet. Sci. Lett., 89, 363-374, doi:10.1016/0012-821X(88)90123-9.

Francheteau, J., R. Armijo, J. L. Cheminée, R. Hékinian, P. Lonsdale, and N. Blum (1990), 1 Ma East Pacific Rise oceanic crust and uppermost mantle exposed by rifting in Hess Deep (equatorial Pacific Ocean), Earth Planet. Sci. Lett., 101, 281-295, doi:10.1016/0012-821X(90)90160-Y.

Gillis, K. M. (1995), Controls on hydrothermal alteration in a section of fast-spreading oceanic crust, Earth Planet. Sci. Lett., 134, 473-489, doi:10.1016/0012-821X(95)00137-2.

Gillis, K. M., K. Muehlenbachs, M. Stewart, T. Gleeson, and J. Karson (2001), Fluid flow patterns in fast spreading East Pacific Rise crust exposed at Hess Deep, J. Geophys. Res., 106(B11), 26,311-26,329, doi:10.1029/2000JB000038.

Gillis, K. M., L. A. Coogan, and R. Pedersen (2005), Strontium isotope constraints in fluid flow in the upper oceanic crust at the East Pacific Rise, Earth Planet. Sci. Lett., 232, 83-94, doi:10.1016/j.epsl.2005.01.008.

Heft, K. L., K. M. Gillis, M. A. Pollock, J. A. Karson, and E. M. Klein (2008), Role of upwelling hydrothermal fluids in the development of alteration patterns at fast spreading ridges: Evidence from the sheeted dike complex at Pito Deep, Geochem. Geophys. Geosyst., 9, Q05007, doi:10.1029/2007GC001926.

Hékinian, R., J. Francheteau, R. Armijo, J. P. Cogne, M. Constanti, J. Girardeau, R. Hey, D. F. Naar, and R. Searle (1996), Petrology of the Easter microplate region in the South Pacific, J. Volcanol. Geotherm. Res., 72, 259-289, doi:10.1016/0377-0273(96)00013-3.

Hess, J., M. L. Bender, and J.-G. Schilling (1986), Evolution of the ratio of strontium-87 to strontium-86 in seawater from Cretaceous to present, Science, 231, 979-984, doi:10.1126/ science.231.4741.979.

Hey, R., G. L. Johnson, and A. Lowrie (1977), Recent plate motions in the Galapagos area, Geol. Soc. Am. Bull., 88, 13851403, doi:10.1130/00167606(1977)88<1385:RPMITG> 2.0.CO;2.

Hey, R. N., P. D. Johnson, F. Martinez, J. Korenga, M. L. Somers, Q. J. Huggett, T. P. LeBas, R. I. Rusby, and D. F. Naar (1995), Plate boundary reorganization at a large-offset, rapidly propagating rift, Nature, $378,167-170$, doi:10.1038/ $378167 \mathrm{a} 0$.

Hey, R. N., et al. (2002), Preliminary attempt to characterize the rotation of seafloor in the Pito Deep area of the Easter Microplate using a submersible magnetometer, Mar. Geophys. Res., 23, 1-12, doi:10.1023/A:1021257915420.

Hilgen, F. J., W. Krijgsman, C. G. Langereis, L. J. Lourens, A. Santarelli, and W. J. Zachariasse (1995), Extending the astronomical (polarity) time scale into the Miocene, Earth Planet. Sci. Lett., 136, 495-510, doi:10.1016/0012821X(95)00207-S.

Hinkley, T. K., and M. Tatsumoto (1987), Metals and isotopes in Juan de Fuca ridge hydrothermal fluids and their associated solid materials, J. Geophys. Res., 92(B11), 11,40011,410, doi:10.1029/JB092iB11p11400.

Hofmann, A. W., and W. M. White (1982), Mantle plumes from ancient oceanic crust, Earth Planet. Sci. Lett., 57, 421-436, doi:10.1016/0012-821X(82)90161-3.
Karson, J. A. and Pito Deep Shipboard Scientific Party (2005), Pito Deep cruise report, Dep. of Earth Sci., Syracuse Univ., Syracuse, N.Y.

Karson, J. A., et al. (2002), Structure of uppermost fast-spread oceanic crust exposed at the Hess Deep Rift: Implications for subaxial processes at the East Pacific Rise, Geochem. Geophys. Geosyst., 3(1), 1002, doi:10.1029/2001GC000155.

Kusakabe, M., T. Shibata, M. Yamamoto, S. Mayeda, H. Kagami, H. Honma, H. Masuda, and H. Sakai (1989), Petrology and isotope characteristics $(\mathrm{H}, \mathrm{O}, \mathrm{S}, \mathrm{Sr}$, and $\mathrm{Nd})$ of basalts from Ocean Drilling program Hole 504B, Proc. Ocean Drill. Program Sci. Results, 111, 47-60.

Laverne, C., D. A. Vanko, P. Tartarotti, and J. C. Alt (1995), Chemistry and geothermometry of secondary minerals from the deep sheeted dike complex, DSDP/ODP Hole 504B, Proc. Ocean Drill. Program Sci. Results, 137/140, 167-189.

Laverne, C., P. Agrinier, D. Hermitte, and M. Bohn (2001), Chemical fluxes during hydrothermal alteration of a $1200-\mathrm{m}$ long section of dikes in the oceanic crust, DSDP/ODP Hole 504B, Chem. Geol., 181, 73-98, doi:10.1016/S00092541(01)00277-7.

Lonsdale, P. (1988), Structural pattern of the Galapagos Microplate and evolution of the Galapagos Triple Junction, J. Geophys. Res., 93(B11), 13,551-13,574, doi:10.1029/ JB093iB11p13551.

Mahoney, J. J., J. M. Sinton, M. D. Kurz, J. D. Macdougall, K. J. Spencer, and G. W. Lugmair (1994), Isotope and trace element characteristics of a super-fast spreading ridge: East Pacific rise, $13-23^{\circ} \mathrm{S}$, Earth Planet. Sci. Lett., 121, $173-$ 193, doi:10.1016/0012-821X(94)90039-6.

Martinez, F., D. F. Naar, T. B. Reed, and R. N. Hey (1991), Three-dimensional SEAMARC II, gravity and magnetics study of large-offset rift propagation at the Pito Rift, Easter Microplate, Mar. Geophys. Res., 13, 255-285, doi:10.1007/ BF00366279.

McKay, G., L. Le, J. Wagstaff, and G. Crozaz (1994), Experimental partitioning of rare earth elements and strontium: Constraints on petrogenesis and redox conditions during crystallization of Antarctic angrite Lewis Cliff 86010, Geochim. Cosmochim. Acta, 58, 2911-2919, doi:10.1016/00167037(94)90124-4.

Merlivat, L., F. Pineau, and M. Javoy (1987), Hydrothermal vent waters at $13^{\circ} \mathrm{N}$ on the East Pacific Rise: Isotopic composition and gas concentration, Earth Planet. Sci. Lett., 84, 100-108, doi:10.1016/0012-821X(87)90180-4.

Palmer, M. R. (1992), Controls over the chloride concentration of submarine hydrothermal vent fluids: Evidence from $\mathrm{Sr} / \mathrm{Ca}$ and ${ }^{87} \mathrm{Sr} /{ }^{86} \mathrm{Sr}$ ratios, Earth Planet. Sci. Lett., 109, 37-46, doi:10.1016/0012-821X(92)90072-4.

Palmer, M. R., and J. M. Edmond (1989), The strontium isotope budget of the modern ocean, Earth Planet. Sci. Lett., 92, 11-26, doi:10.1016/0012-821X(89)90017-4.

Perk, N. W., L. A. Coogan, J. A. Karson, E. M. Klein, and H. D. Hanna (2007), Petrology and geochemistry of primitive lower oceanic crust from Pito Deep: Implications for the accretion of the lower crust at the southern East Pacific Rise, Contrib. Mineral. Petrol., 154, doi:10.1007/s00410-0070210-z.

Piepgras, D. J., and G. J. Wasserburg (1985), Strontium and neodymium isotopes in hot springs on the East Pacific Rise and Guaymas Basin, Earth Planet. Sci. Lett., 72, 341-356, doi:10.1016/0012-821X(85)90057-3.

Schiffman, P., B. M. Smith, R. J. Varga, and E. M. Moores (1987), Geometry, conditions and timing of off-axis hydro- 
thermal metamorphism and ore-deposition in the Solea graben, Nature, 325, 423-425, doi:10.1038/325423a0.

Schilling, J. G., D. Fontignie, J. Blichert-Toft, R. H. Kingsley, and U. Tomza (2003), Pb-Hf-Nd-Sr isotope variations along the Galapagos spreading center $\left(101^{\circ}-83^{\circ} \mathrm{W}\right)$ : Constraints on the dispersal of the Galapagos mantle plume, Geochem. Geophys. Geosyst., 4(10), 8512, doi:10.1029/2002GC000495.

Seyfried, W. E. (1987), Experimental and theoretical constraints on hydrothermal alteration processes at mid-ocean ridges, Annu. Rev. Earth Sci., 15, 317-335, doi:10.1146/ annurev.ea.15.050187.001533.

Tang, D. H., E. O. Frind, and E. A. Sudickey (1981), Contamination transport in fractured porous media: analytical solution for a single fracture, Water Resour. Res., 17, 555-564, doi:10.1029/WR017i003p00555.

Taylor, H. P. (1977), Water/rock interaction and the origin of $\mathrm{H}_{2} \mathrm{O}$ in granitic batholiths, J. Geol. Soc., 133(6), 509-558, doi:10.1144/gsigs.133.6.0509.

Teagle, D. A. H., J. C. Alt, and A. N. Halliday (1998a), Tracing the chemical evolution of fluids during hydrothermal recharge: Constraints from anhydrite recovered in ODP Hole 504B, Earth Planet. Sci. Lett., 155, 167-182, doi:10.1016/ S0012-821X(97)00209-4.

Teagle, D. A. H., J. C. Alt, and A. N. Halliday (1998b), Tracing the chemical evolution of fluids in the upper oceanic crust: $\mathrm{Sr}$ isotopic constraints from DSDP/ODP Holes 504B and 896A, in Modern Ocean Floor Processes and the Geological Record, edited by R. A. Mills and K. Harrison, Geol. Soc. Spec. Publ., 148, 81-97.
Teagle, D. A. H., M. J. Bickle, and J. C. Alt (2003), Recharge flux to ocean-ridge black smoker systems: a geochemical estimate from ODP Hole 504B, Earth Planet. Sci. Lett., 210, 81-89, doi:10.1016/S0012-821X(03)00126-2.

Vanko, D. A., C. Laverne, P. Tartorotti, and J. C. Alt (1996), Chemistry and origin of secondary minerals from, the deep sheeted dikes cored during ODP Leg 148, Hole 504B, Proc. Ocean Drill. Program Sci. Results, 148, 71-86.

Verma, S. P., and J. G. Schilling (1982), Galapagos Hotspot spreading center system: $2 .{ }^{87} \mathrm{Sr} /{ }^{86} \mathrm{Sr}$ and large ion lithophile element variations $\left(85^{\circ} \mathrm{W}-101^{\circ} \mathrm{E}\right), J$. Geophys. Res., 87, 10,838-10,856, doi:10.1029/JB087iB13p10838.

Von Damm, K. L. (1990), Seafloor hydrothermal activity: Black smoker chemistry and chimneys, Annu. Rev. Earth Planet. Sci., 18, 173-204, doi:10.1146/annurev.ea.18.050190.001133

Von Damm, K. L. (1995), Controls on the chemistry and temporal variability of seafloor hydrothermal fluids, in Seafloor Hydrothermal Systems: Physical, Chemical, Biological and Geological Interactions, Geophys. Monogr. Ser, vol. 91, edited by S. E. Humphris et al., pp. 222-247, AGU, Washington, D.C.

Von Damm, K. L. (2000), Chemistry of hydrothermal vent fluids from $9^{\circ}-10^{\circ} \mathrm{N}$, East Pacific Rise: "Time zero," the immediate posteruptive period, J. Geophys. Res., 105(B5), 11,203-11,222, doi:10.1029/1999JB900414.

Weis, D., et al. (2006), High-precision isotopic characterization of USGS reference materials by TIMS and MC-ICP-MS, Geochem. Geophys. Geosyst., 7, Q08006, doi:10.1029/ 2006GC001283. 